\title{
19. SITE SURVEYS FROM HONOLULU TO TOKYO (SCAN III) AND TOKYO TO GUAM (SCAN IV)
}

\author{
G. G. Shor, S. D. Einsohn, A. J. Henry, D. A. Johnson and D. Karig, \\ Scripps Institution of Oceanography, La Jolla, California
}

\section{INTRODUCTION}

The respective cruise chief scientists were G. G. Shor for SCAN III and D. Karig for SCAN IV. Data given in the Site Survey Reports was written by S. D. Einsohn, A. J. Henry, D. A. Johnson, D. Karig and G. G. Shor.

The sections on reflection profiles, Hawaiian Ridge, Survey 22 , Survey 11 , Survey $12 \mathrm{~A}$, and Survey 15 were written by G. G. Shor.

A detailed account of surveying on SCAN IV in the Mariana area is given by D. Karig in Chapter 20 of this volume.

The cooperation of Capt. J. Bonham, Leg III and Capt. C. Clampitt, Leg IV and the crew and shipboard staff is appreciated. Data preparation was made by A. Henry, S. Smith, A. Raff, A. Gallie and R. Mann.

Areas of interest selected for Leg 6 by the JOIDES Pacific Advisory Panel were surveyed by the R/V Argo on Expedition SCAN of Scripps Institution of Oceanography. These surveys made it possible to choose the best locations for drilling by the Glomar Challenger. The site survey information forms a basic framework to assist in any regional interpretations that may be made on the results of subsequent drilling by the Challenger.

The track chart (Figure 1) shows the location of the SCAN surveys and the corresponding Glomar Challenger drill site numbers. The following list relates Argo (SCAN) Survey site numbers with the drilled site numbers of the Glomar Challenger.

$\begin{array}{cc}\text { Argo (SCAN) } & \begin{array}{c}\text { Glomar Challenger } \\ \text { Surveys }\end{array} \\ 11 & \text { Drill Sites } \\ 12 & 44 \\ \text { No survey } & 45 \\ 13 \mathrm{~A} & 46 \\ 13 \mathrm{~B} & 47 \\ 14 \mathrm{~A} & 48 \\ 14 \mathrm{~B} & 49 \\ 15 & 50 \\ \text { No survey } & 51 \\ 17 & 52 \\ \text { No surveys } & 53 \\ 18 \mathrm{~A} & 54 \text { to } 59 \\ \end{array}$

Each SCAN survey consisted of an underway grid and a sampling station at the place that was considered to be the most suitable for a drilling location. The vessel was equipped with a satellite navigation system and LORAN C. The underway survey was conducted utilizing a reflector profiler, $12.5-\mathrm{kHz}$ echo sounder, $3.5-\mathrm{kHz}$ echo sounder, and a magnetometer. On site, a piston core, bottom photographs, and a heat flow measurement were taken.

All depths on the seismic profile record (reproduced at the end of this chapter) are in seconds of two-way acoustic travel time.

\section{SITE SURVEY REPORTS}

\section{Site Survey 11 (15-17 May, 1969). Site 44}

Weather conditions: Wind ENE 15 knots; sky partly cloudy; sea ENE moderate; swell NNE 4 to 6 feet; barometer 30.01 ; air temperature $78^{\circ} \mathrm{F}$.; sea temperature $78^{\circ} \mathrm{F}$.

Drift: Greater than one knot to SW.

Topography: Flat topped ridge on smooth floor.

Seismic profiles: On top of ridge sediment layered and relatively transparent.

Magnetics: Three hundred gamma anomaly over top of ridge.

Photographs of sea floor: Camera lowering 9 at $10^{\circ}$ $27^{\prime} \mathrm{N}, 168^{\circ} 59^{\prime} \mathrm{W}$. Pictures revealed black porous rocks on bottom (possibly basalt or manganese coated coral) with intermittent patches of rippled sand. Camera lowering 10 at $19^{\circ} 17.8^{\prime} \mathrm{N}, 169^{\circ}$ $05.3^{\prime} \mathrm{W}$ near crest of ridge. Pictures revealed a rippled sand bottom. Camera lowering 11 at $19^{\circ} 24.4^{\prime} \mathrm{N}$, $169^{\circ} 08.3^{\prime} \mathrm{W}$ near break in slope on northwest side of ridge. Pictures show large areas of rippled sand with isolated outcrops of rock.

Heat flow: No measurements made here.

Sediment cores: Two gravity cores were attempted near $19^{\circ} 27.0^{\prime} \mathrm{N}, 168^{\circ} 59^{\prime} \mathrm{W}$; both cores came up empty, with no trace of sediments either on the core barrel or in the core liner. On the second lowering the threads connecting the barrel and weight stand were broken, indicating that the core barrel contacted a hard bottom. 


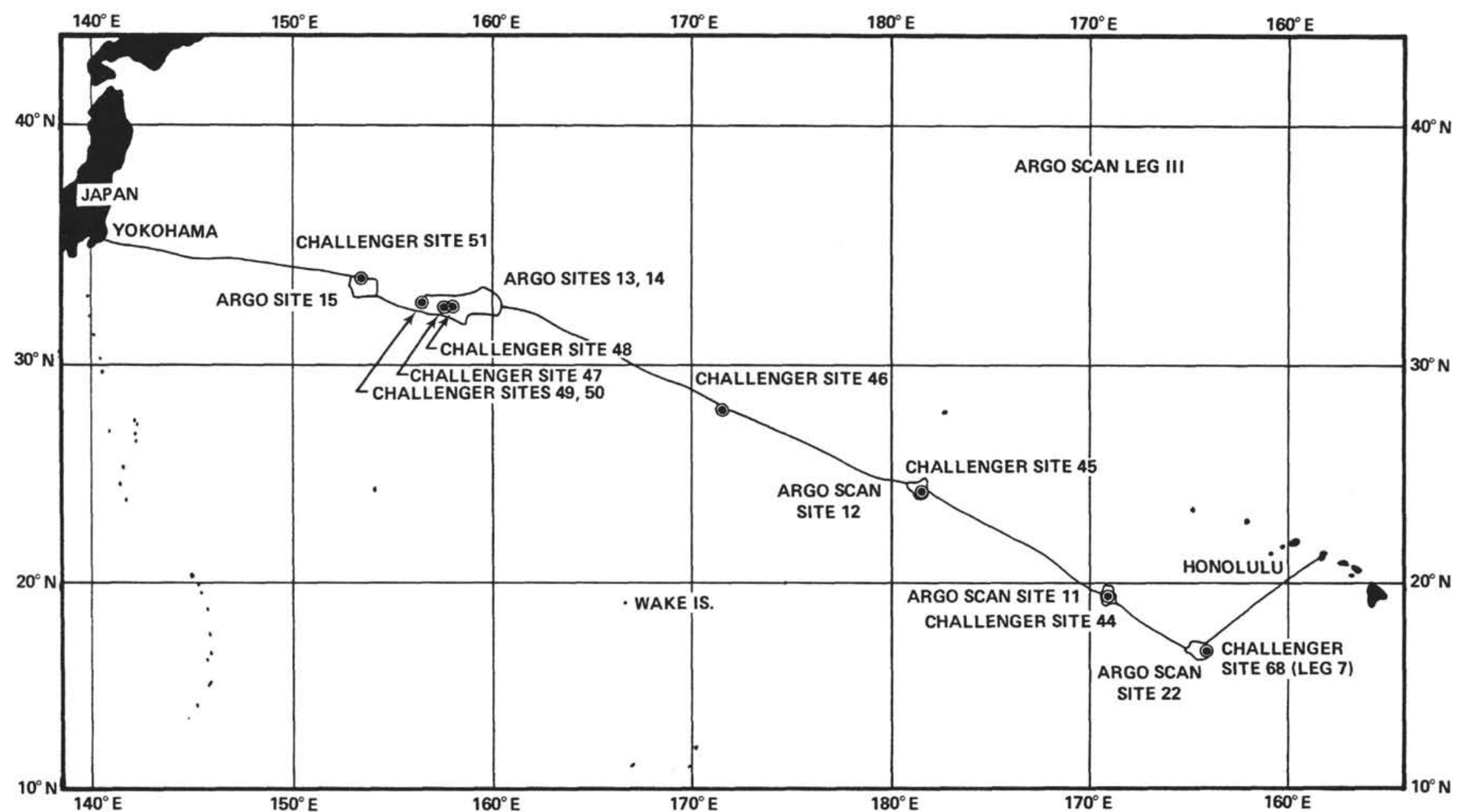

Figure 1. Generalized track of Argo SCAN III Expedition. 


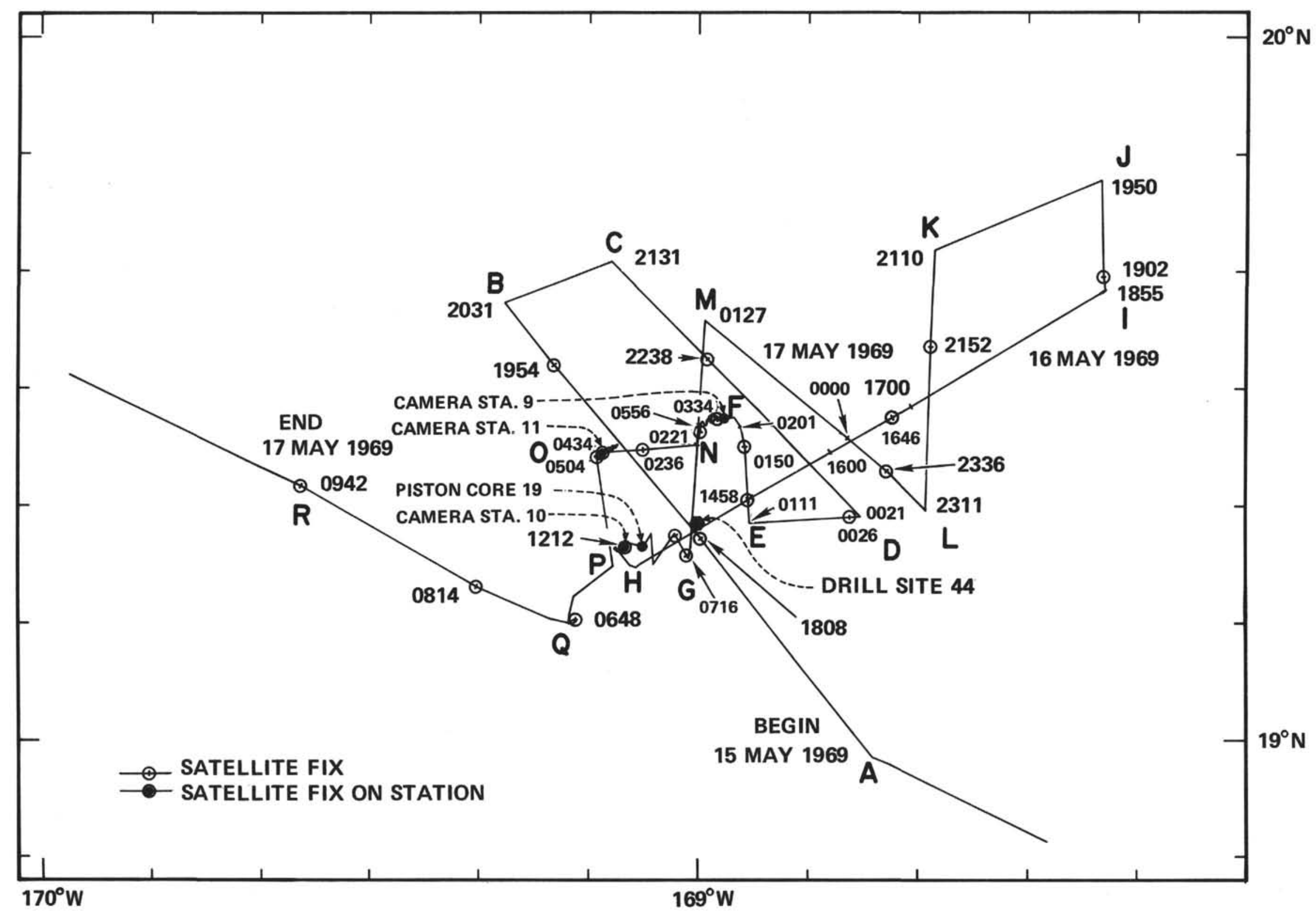

Figure 2. Glomar Challenger Site 44, Argo (SCAN) Site 11. 
Piston Core 19 and gravity core tripping weight 19 were lowered near the top of the ridge at $19^{\circ} 17.8^{\prime} \mathrm{N}, 168^{\circ}$ $05.3^{\prime} \mathrm{W}$. The gravity core came up empty. The lower rim of the catcher of the piston core held some loose white sandy sediment of Recent age. The rest of the core contained water which had sediment suspended in it. The suspended material contained foraminifera and less common Radiolaria. It is probable that the catcher of the piston core was unable to retain the foraminiferal sand when the cover was raised. The samples were thoroughly checked for contamination from older horizons, but none was found.

Analysis of sediment from Core 19: Preservation of foraminifera recovered from the catcher was variable. Non-species specific variation in preservation included typical earthen white, pearly luster, and redbrown staining. Of the foraminifera, 95 per cent were intact. Relative size of all species was large.

Faunal list: Age - Recent

Globigerina rubescens

Orbulina universa

Globigerinoides conglobatus

Globigerina digitata

Globorotalia cultrata

Globorotalia truncatulinoides

Globigerinoides ruber

Globigerinoides quadrilobatus sacculifer

Globigerinella siphonifera

Sphaeroidinella dehiscens

Globigerina bulloides

Globorotalia pumilio

Pulleniatina obliquiloculata

Candeina nitida

\section{Site Survey 12 (19-21 May, 1969) Site 45}

Weather conditions: Wind ENE 13 knots; sky mostly cloudy; sea moderate; swell 3 to 4 feet; barometer 29.96; air temperature $76^{\circ} \mathrm{F}$; sea temperature $75^{\circ} \mathrm{F}$.

Drift: Small and variable in direction.

Topography: Depth 2900 to 3100 fathoms with very low relief.

Seismic profiles: Prominent reflectors at 0.015 to 0.025 seconds and at 0.4 seconds below sea floor.

Magnetics: Low magnetic anomalies $<100$ gammas except for possible northeast oriented anomalies of 300 gammas at northern and southern ends of the surveyed area.
Photographs of sea floor: Camera station 12 revealed a smooth almost featureless floor.

Heat Flow: $1.06 \mu \mathrm{cal} / \mathrm{sec} / \mathrm{cm}^{2}$. The conductivity of the sediment at 0 centimeters was $2.16 \times 10^{-3} / \mathrm{cal} / \mathrm{cm} /$ $\mathrm{X}^{\circ} \mathrm{C} / \mathrm{sec}$.

Sediment cores: Piston Core 20 and Gravity Core 20 located at $178^{\circ} 30.2^{\prime} \mathrm{W}, 24^{\circ} 08.6^{\prime} \mathrm{N}$.

Water depth: 5606 meters.

Core length: 922 centimeters;-siliceous ooze and red clay with foraminifera (Middle Eocene to Upper Cretaceous) in the interval 444 to 922 centimeters. Angular chert fragments and rounded black rock fragments also present.

Faunal list:

\section{Globotruncana calcaratta}

Globotruncana rosetta

Globotruncana hilli

Globotruncana linneiana (elevata?)

Heterohelix sp.

Hedbergella sp.

Site Surveys 13 and 14 (27 May to 2 June, 1969) Sites 47-50

Drift: Various currents, severe at times.

Topography: Rough.

Seismic profiles: Horizons $\mathrm{A}^{\prime}$ and $\mathrm{B}^{\prime}$ are well-developed in the deeper waters east and west of the rise. On the east flank of the rise there are two areas where Horizon B' seems to outcrop. West of the eastern outcrop area the section thickens greatly and many new reflectors appear. Horizon $\mathrm{A}^{\prime}$ becomes difficult to identify, since pinchouts and separations occur at frequent intervals. Many of the profiles show basement peaks rising up to or through the sea floor, making correlations across them suspect.

Magnetics: Anomalies of 200 to 400 gammas. Any lineation, if present, not determined from this survey.

Photographs of sea floor: The photographs of this area show a smooth floor. Some areas have what appear to be plate-like nodules.

Heat flow: Station 13 at $32^{\circ} 15.2^{\prime} \mathrm{N}, 159^{\circ} 15.8^{\prime} \mathrm{E}$ has value of $0.69 \mu \mathrm{cal} / \mathrm{sec} / \mathrm{cm}^{2}$. Station 14 at $32^{\circ} 15.1^{\prime} \mathrm{N}$, $157^{\circ} 40.4^{\prime} \mathrm{E}$ has a value of $0.76 \mu \mathrm{cal} / \mathrm{sec} / \mathrm{cm}^{2}$.

Sediment cores: Piston Core 22 at $32^{\circ} 20.4^{\prime} \mathrm{N}, 159^{\circ}$ $14.9^{\prime} \mathrm{E}$. Core length 959 centimeters; upper third buff-tan calcareous ooze, middle portion light brown calcareous ooze, lower third dark brown indurated calcareous ooze.

Piston Core 23 at $32^{\circ} 18.8^{\prime} \mathrm{N}, 159^{\circ} 13.1^{\prime} \mathrm{E}$. Core length 1134 centimeters, calcareous foraminiferal ooze. 


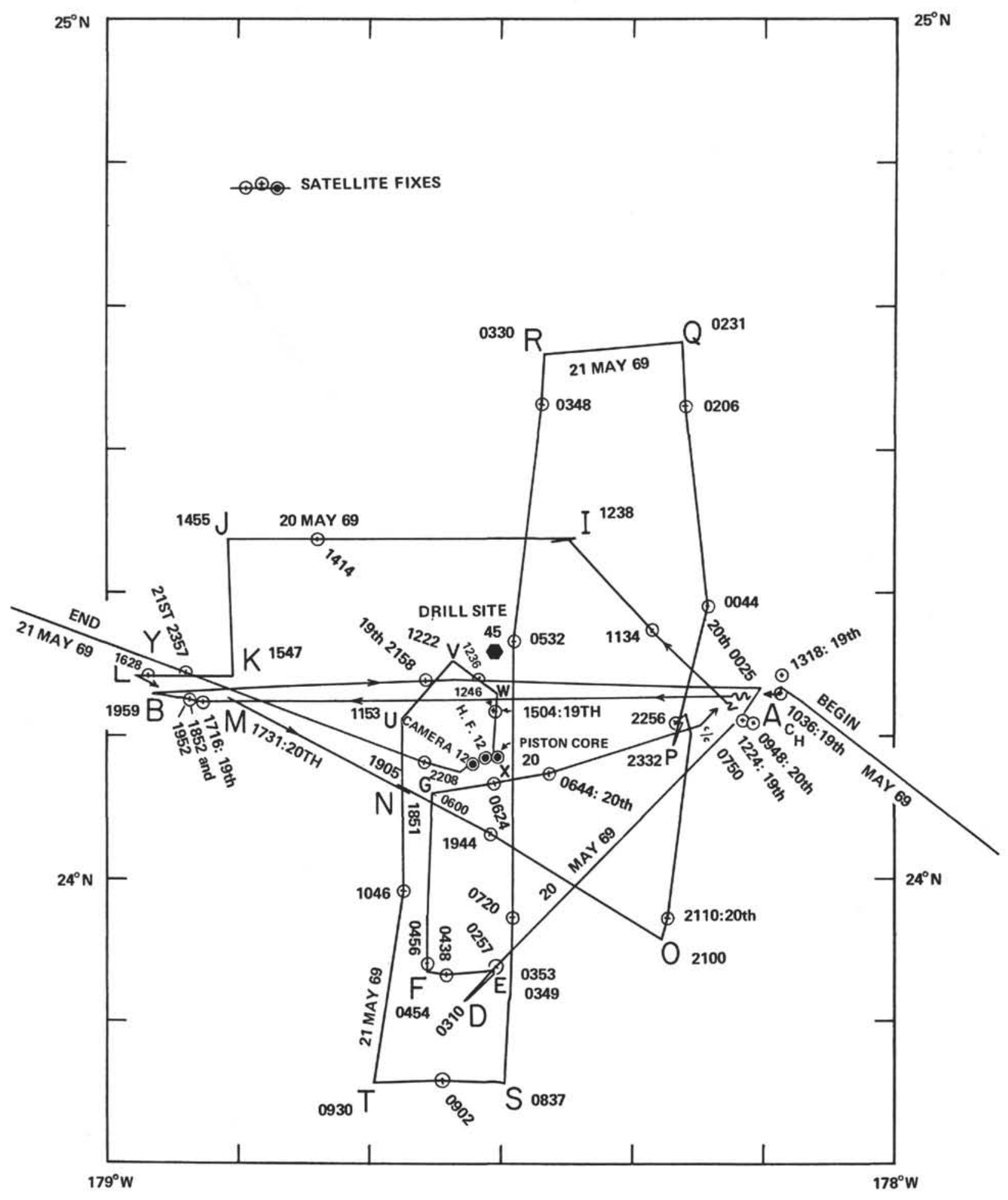

Figure 3. Glomar Challenger Site 45, Argo (SCAN) Site 12. 


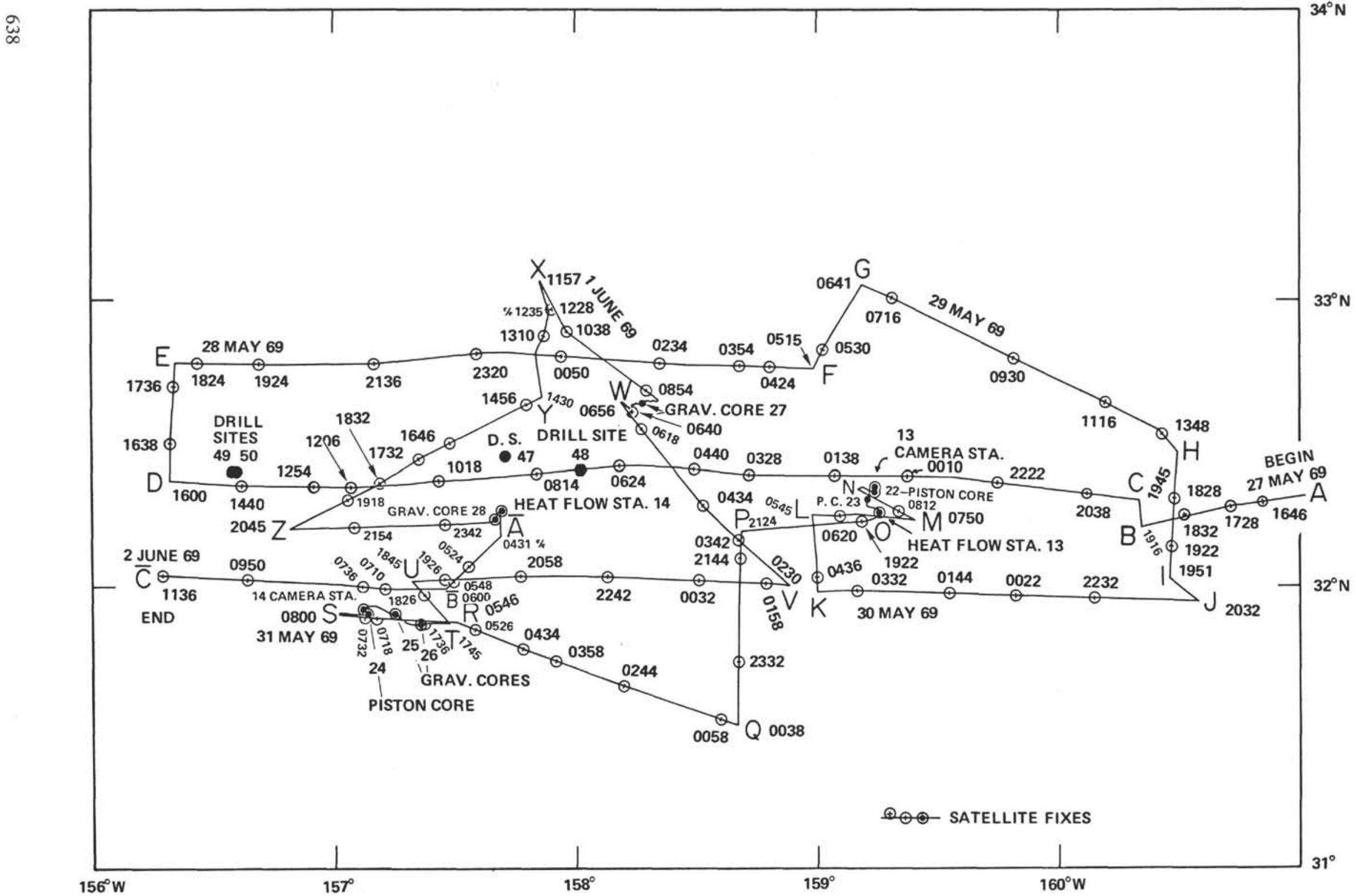

Figure 4. Glomar Challenger Sites 47, 48, 49 and 50, Argo (SCAN) Sites 13A, 13B, 14A and 14B. 
Piston Core 24 at $31^{\circ} 54.3^{\prime} \mathrm{N}, 159^{\circ} 08.2^{\prime} \mathrm{E}$. Core length 159 centimeters, brown siliceous ooze, black weathered basalt recovered in catcher, core barrel bent.

Gravity Core 25 at $31^{\circ} 53.9^{\prime} \mathrm{N}, 157^{\circ} 14.8^{\prime} \mathrm{E}$. Core length 64 centimeters, light brown calcareous ooze.

Gravity Core 27 at $32^{\circ} 37.0^{\prime} \mathrm{N}, 158^{\circ} 14.2^{\prime} \mathrm{E}$. Core length 10 centimeters, foraminiferal sand, with one rock fragment (coral?).

Gravity Core 28 at $32^{\circ} 13.9^{\prime} \mathrm{N}, 157^{\circ} 39.8^{\prime} \mathrm{E}$. Core length 45 centimeters, foraminiferal sand.

Faunal list: All calcareous material is Miocene in age.

\section{Globoquadrina dehiscens \\ Pulleniatina obliquiloculata \\ Orbulina universa \\ Sphaeroidinella dehiscens}

Site Survey 15 (3-6 June, 1969) Site 51

Weather conditions: 4 June at 1400 hours. Wind SSE 20 knots; sea SSE moderate; swell SSE 4 to 6 feet; barometer 30.04 ; air temperature $73^{\circ} \mathrm{F}$.; water temperature $70^{\circ} \mathrm{F}$.

Drift: Small, generally to the south or southwest.

Topography: Regional depth 2800 to 3200 fathoms. Broad, gentle slopes with inclination of less than 1:1000. No abyssal hills or other small scale features.

Seismic profiles: Prominent reflectors occur at 0.10 to 0.15 seconds and at 0.25 to 0.30 seconds beneath the sea floor. Relief of reflectors is conformable with overlying sea floor.

Magnetics: Anomalies of 500 to 800 gammas lineated in an east-west direction.

Photographs of sea floor: Camera lowering 15 shows smooth floor.

Heat flow: Location $33^{\circ} 18.7^{\prime} \mathrm{N}, 153^{\circ} 44.4^{\prime} \mathrm{E} ; 1.00$ $\mu \mathrm{cal} / \mathrm{sec} / \mathrm{cm}^{2}$.

Sediment cores: Piston Core $29 \mathrm{~A}$ at $33^{\circ} 23.2^{\prime} \mathrm{N}, 153^{\circ}$ $45.9^{\prime} \mathrm{E}$ in water depth of 3117 fathoms. Core length 150 centimeters; brown siliceous ooze. Piston Core $29 \mathrm{~B}$ at $33^{\circ} 16.4^{\prime} \mathrm{N}, 153^{\circ} 43.7^{\prime} \mathrm{E}$ in water depth of 3098 fathoms. Core length 1118 centimeters; brown radiolarian ooze.

\section{Site Survey 17 (21-23 June, 1969) Site 53}

Weather: Wind east 15 knots; sky partly cloudy; sea moderate from east; swell SE nine feet; barometer 29.9; air temperature $86^{\circ} \mathrm{F}$.; water temperature $84^{\circ} \mathrm{F}$.

Drift: In easterly direction 0.5 knot.

Topography: Regional depth 2500 fathoms with 150 fathoms of relief. Valleys trending NNE and coincide with deepest sediments. The basement follows the relief.
Seismic profiles: These are discussed in considerable detail in Chapter 20.

Photographs of sea floor: Camera lowering 16 at $18^{\circ}$ $01^{\prime} \mathrm{N}, 141^{\circ} 05.7^{\prime} \mathrm{E}$. Bottom 30 per cent covered, probably with pumice or volcanic pebbles.

Heat flow: Station 18 at $18^{\circ} 01^{\prime} \mathrm{N}, 141^{\circ} 32^{\prime} \mathrm{E}$ has a value of $1.8 \mu \mathrm{cal} / \mathrm{sec} / \mathrm{cm}^{2}$. Station 19 at $18^{\circ} 16^{\prime} \mathrm{N}$, $140^{\circ} 54^{\prime} \mathrm{E}$ has a value of $1.9 \mu \mathrm{cal} / \mathrm{sec} / \mathrm{cm}^{2}$.

Sediment cores: See Chapter 20.

\section{Site Survey 18A (4-6 July, 1969) Site 60}

Weather conditions: Wind ENE 12 knots; sky partially cloudy; sea ENE moderate; swell east eight feet; barometer 29.84; air temperature $86^{\circ} \mathrm{F}$.; water temperature $80^{\circ} \mathrm{F}$.

Drift: To ENE at five knots.

Topography: East facing slope between Mariana Ridge and the trench. Local topography is hummocky. No canyons were noted in this area.

Seismic profiles: See Chapter 20.

Magnetics: The magnetic field was characterless. The daily variation exceeded the local anomaly amplitudes.

Photographs of the sea floor: Camera malfunctioned; no pictures.

Heat flow: Showed inverted temperature gradient. A station to the north in similar setting had a value of less than $0.5 \mu \mathrm{cal} / \mathrm{sec} / \mathrm{cm}^{2}$.

Sediment cores: See Chapter 20.

\section{REFLECTION PROFILES}

Reflection records were made from the $R / V$ Argo on Expedition Scan III along a track from Honolulu, Hawaii, To Tokyo, Japan, via Survey Areas 22, 11, $12 \mathrm{~A}, 13,14$ and 15, in that order. A generalized track is shown in Figure 1. Sound sources used were Bolt PAR airguns (normally one; sometimes two at once) with 20-or 30-cubic inch air chambers. The signals were detected with a 150 -foot 20-hydrophone Electrotech EVP-23 streamer, amplified through two separate channels each consisting of a Bolt amplifier and a KrohnHite filter, and recorded on two different recorders at different sweep rates. One record (see profiles following this account) was made on a McKiernan-Terry Mk X PDR with modified input, operated on a 10 -second sweep; a duplicate record was made on an Edo-Western PSR recorder operated on a sweep rate variously set at $1,2,3$ or 4 seconds. Either recorder could operate as the master, triggering the sweep on the other recorder as well as the airgun(s).

Filters were normally set for a 30 to $150 \mathrm{cps}$ bandpass; ship speed was normally 11.5 knots, although for some periods 10.5 -knot or $12-\mathrm{knot}$ speeds were used. 


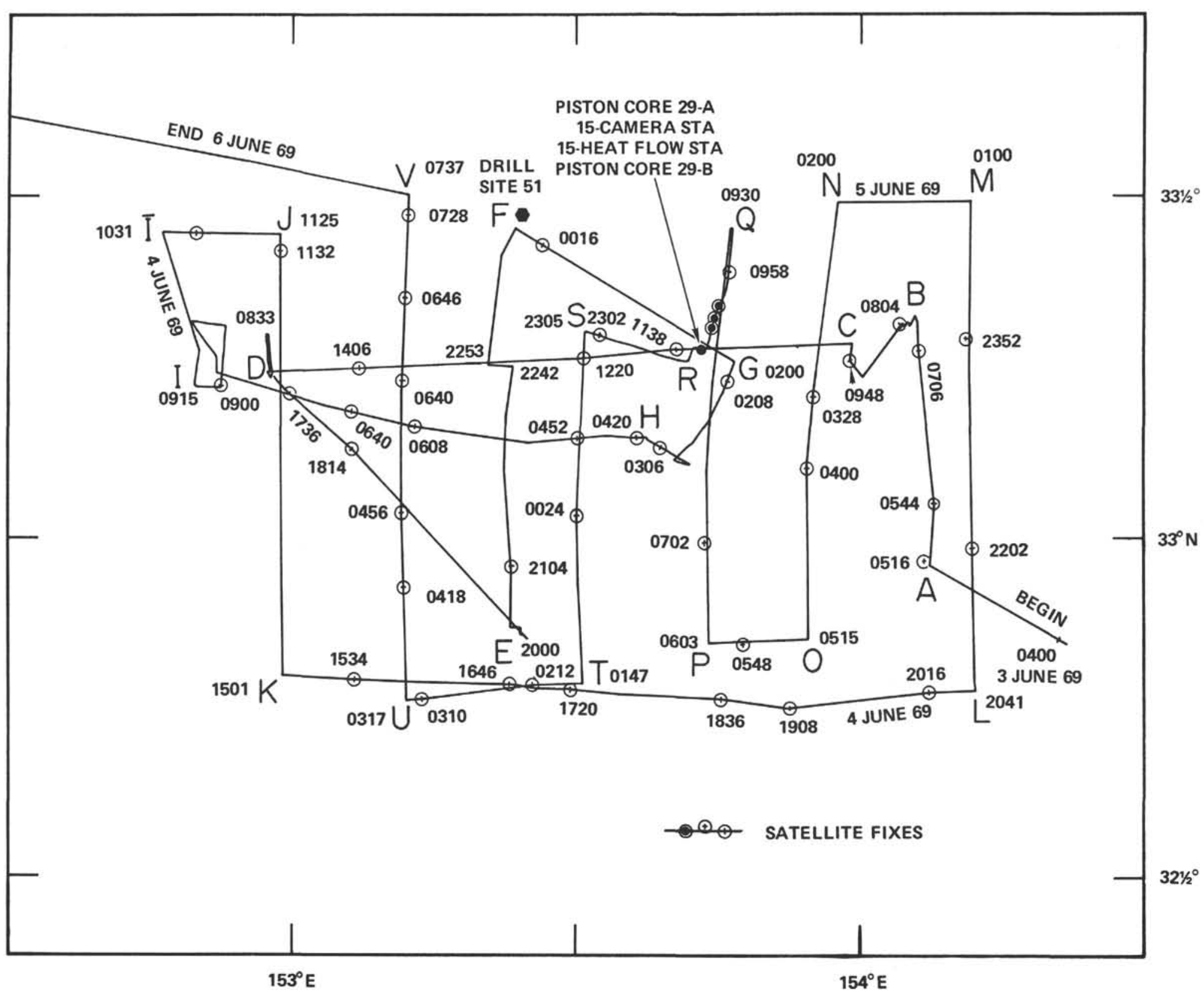

Figure 5. Glomar Challenger Site 51, Argo (SCAN) Site 15. 


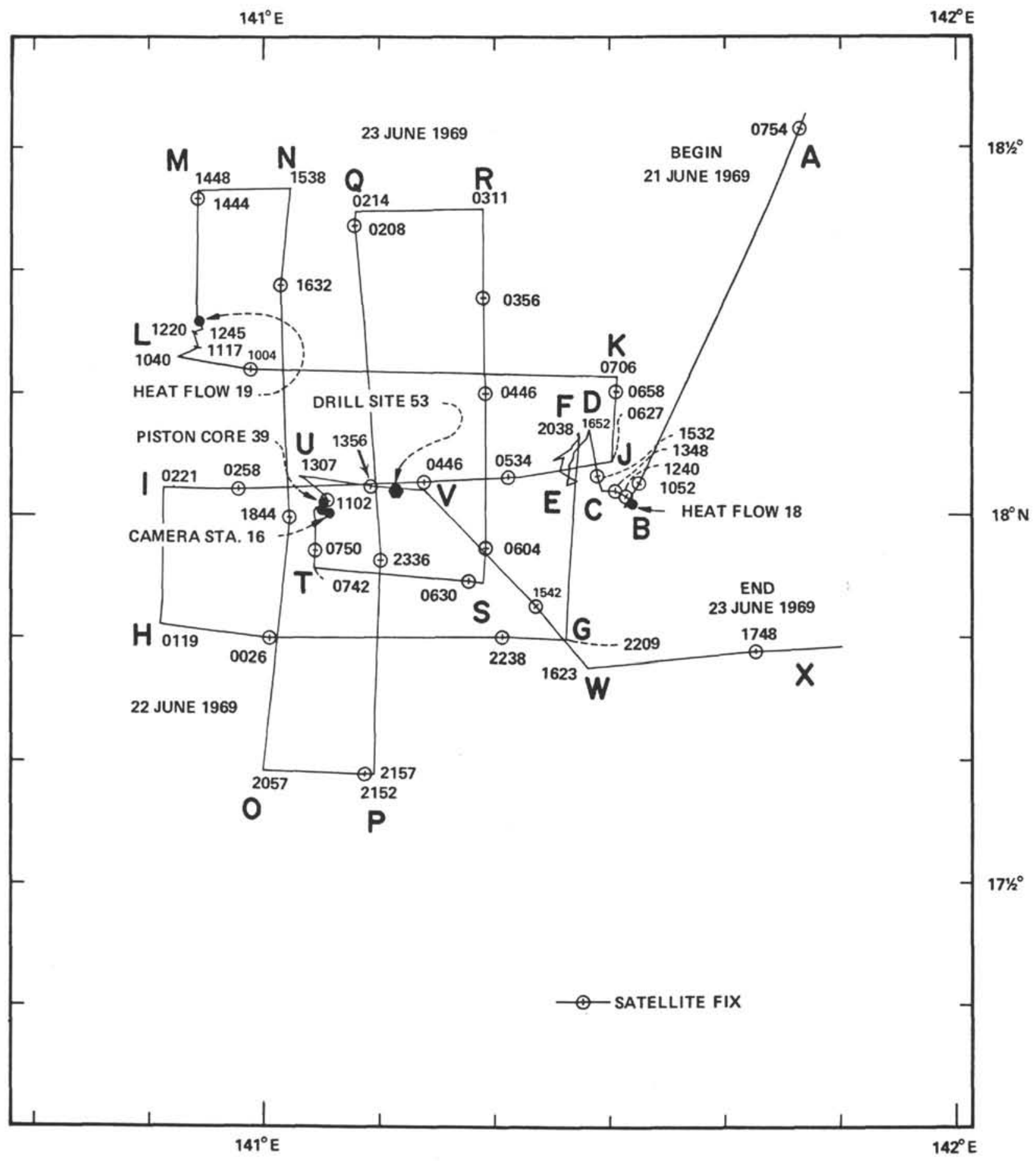

Figure 6. Glomar Challenger Site 53, Argo (SCAN) Site 17. 


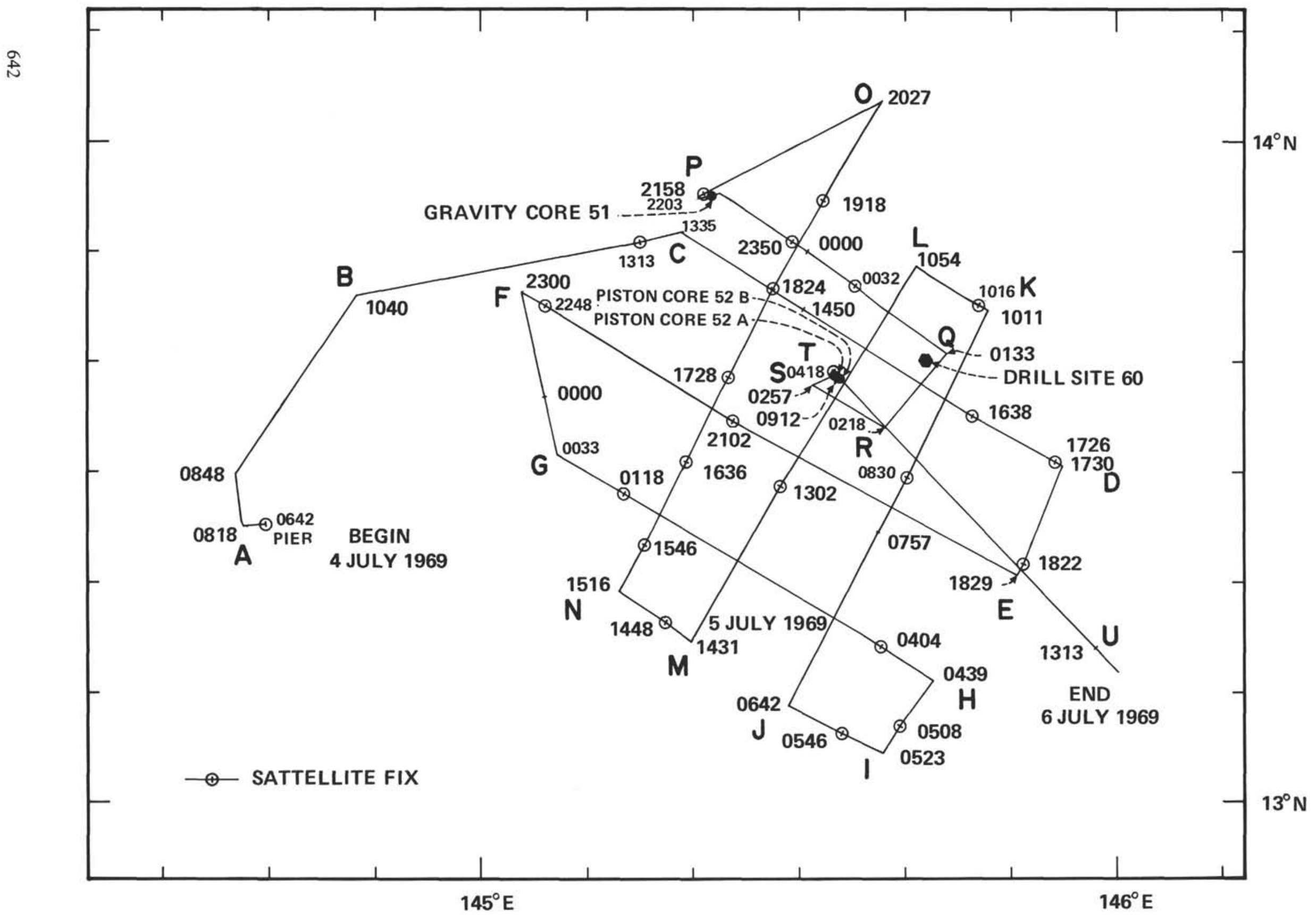

Figure 7. Glomar Challenger Site 60, Argo (SCAN) Site $18 \mathrm{~A}$. 
For uniformity, all of the records shown in the following section are from the 10-second sweep PDR Mk X recorder; in most cases, they have been trimmed down to show only a 4-second interval to permit maximum size of reproduction.

\section{Hawaiian Ridge}

Leaving Pearl Harbor, Hawaii, on course $232^{\circ}$, the track leads down the southwest flank of the Hawaiian Ridge. Little or no penetration was achieved on the steep slope of the ridge; some pockets of sediment were caught on the lower flank of the ridge at a depth of 1600 fathoms. A small unfilled section of the Hawaiian Deep is located at the foot of the slope. Turbidites cover the south flank of the Deep, the Hawaiian Arch beyond, and they surround isolated peaks on the top and south side of the Arch. Turbidites are ponded behind some small ridges. At the barrier at $0600 / 11$ the amount of turbidites in the bottom sediments apparently decreases markedly, and it is possible to distinguish a reflecting horizon about 0.2 second below the sea floor. The south slope of the arch confines to $1700 / 11$, where the sea floor levels off at a depth near 3000 fathoms. Small patches of sediment of low reflectivity (without internal layering) about 0.05 -second thick lie above Horizon $\mathrm{A}^{\prime}$ in places.

\section{Survey 22}

The area of Survey 22 is generally similar to that found south of the Hawaiian Arch, with only small patches of transparent sediment above the strong reflecting layer. A seamount lies in the middle of the survey area; it was crossed twice in the course of the work (Site 22).

Beyond Survey Area 22, Argo was on course $308^{\circ}$ to the foot of Horizon Ridge. The structure of Survey 22 continued with a discontinuous layer of transparent sediment, below it a strong reflector (which sometimes is at the sea floor), and another strong reflector about 0.2 second below. This lower reflector (Ewing's B'?) is sometimes smooth and layered, sometimes rough; small hills occasionally protrude through the sedimentary blanket. A dropped block, probably the extension of the Molokai Fracture Zone, lies between two scarps at $0300 / 15$ and $0730 / 15$. A pronounced thickness of the material above Horizon $B^{\prime}$ (to 0.40 second) occurs just before the base of Horizon Ridge, nearly filling a moat in Horizon B'.

\section{Survey 11}

West of Horizon Ridge, the sediments thicken greatly, Argo was on course $300^{\circ}$, crossing the Mid-Pacific Mountains (Marcus-Necker Ridge) nearly at right angles. The material directly below the sea floor is transparent and has relatively low surface reflectivity; 0.10 second below the sea floor is a very strong smooth reflecting horizon, probably turbidites derived from the mountains to the east and west. Basement disappears beneath the sedimentary accumulation; $\mathrm{a}$ faint reflection at a total depth of 0.75 second below the sea floor may be the basement of Horizon B arrival.

Between $1400 / 17$ and $2300 / 17$ the track crosses the main body of the Mid-Pacific Mountains. Tilted, faulted and gullied accumulations of sediments with discontinuous reflectors lie between the peaks of the mountain range.

Beyond the mountains the bottom becomes highly reflective, multiple reflectors appear, and the entire sedimentary section thickens to 0.4 to 0.5 second. Occasional hills come through the section. At 0000/19 the sea floor rises slightly, the sediment thins, and the track crosses a westward-facing fault scarp. The face of the scarp is sediment-free, and the sea floor (and basement) is about 130 fathoms deeper than to the east.

\section{Survey $12 \mathrm{~A}$}

West of Survey Area 12A the sea floor reflector is strong; about 0.10 second below it another reflector is intermittently visible. A deeper reflector-in places, apparently basement-lies about 0.5 second below sea floor, and is more irregular than the sea floor itself. In places, hills project through the shallow reflector, but are apparently covered by the surface layer. Near $0000 / 23$ (close to $180^{\circ}$ longitude; see Figure 1) a transparent layer appears at the surface with a thickness of about 0.06 second. The layering becomes clearer farther west as the shallow transparent layer becomes thicker and less conformable to the layer beneath. At times hills protrude through the sedimentary section; in other places, the transparent layer disappears and leaves a harder reflector (Horizon $\mathrm{A}^{\prime}$ ?) exposed at the sea floor. The "typical" section is best displayed near 0700/27, where there is 0.06 second of transparent material, an "opaque" zone with another transparent layer beneath it, and another "opaque" zone 0.40 second below the sea floor. The lower opaque zone is smooth in many places, and is presumably older sediments; this corresponds to Ewing's Horizon B'.

At the east flank of the Shatsky Rise the same layering can be followed part way up the flank of the rise to a depth of 2700 fathoms; at this depth there is a steep nonsediment slope, and above the slope the same sequence cannot be recognized.

The disturbed sediments and upraised basement area of the Shatsky Rise continue to the west beyond the survey area at least to $0300 / 3$, where a last small hill lies on a gentle westward slope. Just west of the hill the typical sedimentary sequence found east of the rise resumes: a surface layer of low reflectivity without distinctive internal reflectors is approximately 0.05 -second 
thick. Below this is a more reflective opaque layer (Horizon $A^{\prime}$ ), then another transparent layer, and a smooth lower opaque layer $\left(B^{\prime}\right)$. Survey Area 15 has this structure throughout.

\section{Survey 15}

West of Area 15, near position 0700/6, the upper transparent layer suddenly increases in thickness to 0.2 second. The layer below Horizon $\mathrm{A}^{\prime}$ also thickens to such an extent that reflections from Horizon B' become intermittent. Where it can be seen, this layer is smooth and lies about 0.5 to 0.6 second below the sea floor.

At 0900/7 a seamount is crossed. West of the seamount Horizon $\mathrm{B}^{\prime}$ can no longer be identified, and the upper transparent layer begins to show some internal layering.
At $0000 / 8$ it thickens to 0.33 second. Just beyond this the basement rises to a seamount on the outer ridge of the Japan Trench. At $0800 / 8$ on the west slope of the outer ridge, sediment appears again. Here the transparent layer becomes extremely thick (as much as 0.6 second), and is apparently eroded; slopes, for short distances, are away from the trench. Beyond a small hill the bottom starts to slope downwards to the trench. A thick layer of transparent sediment lies upon the upper portion of the slope down to a depth of 3500 fathoms; beyond this no evidence of sediment can be seen, although it could be present but obscured by side echoes from the steep trench walls. No sediment is discernible on the landward wall of the trench, except on a terrace at a depth of 1200 fathoms where a small amount is trapped behind a hill. 


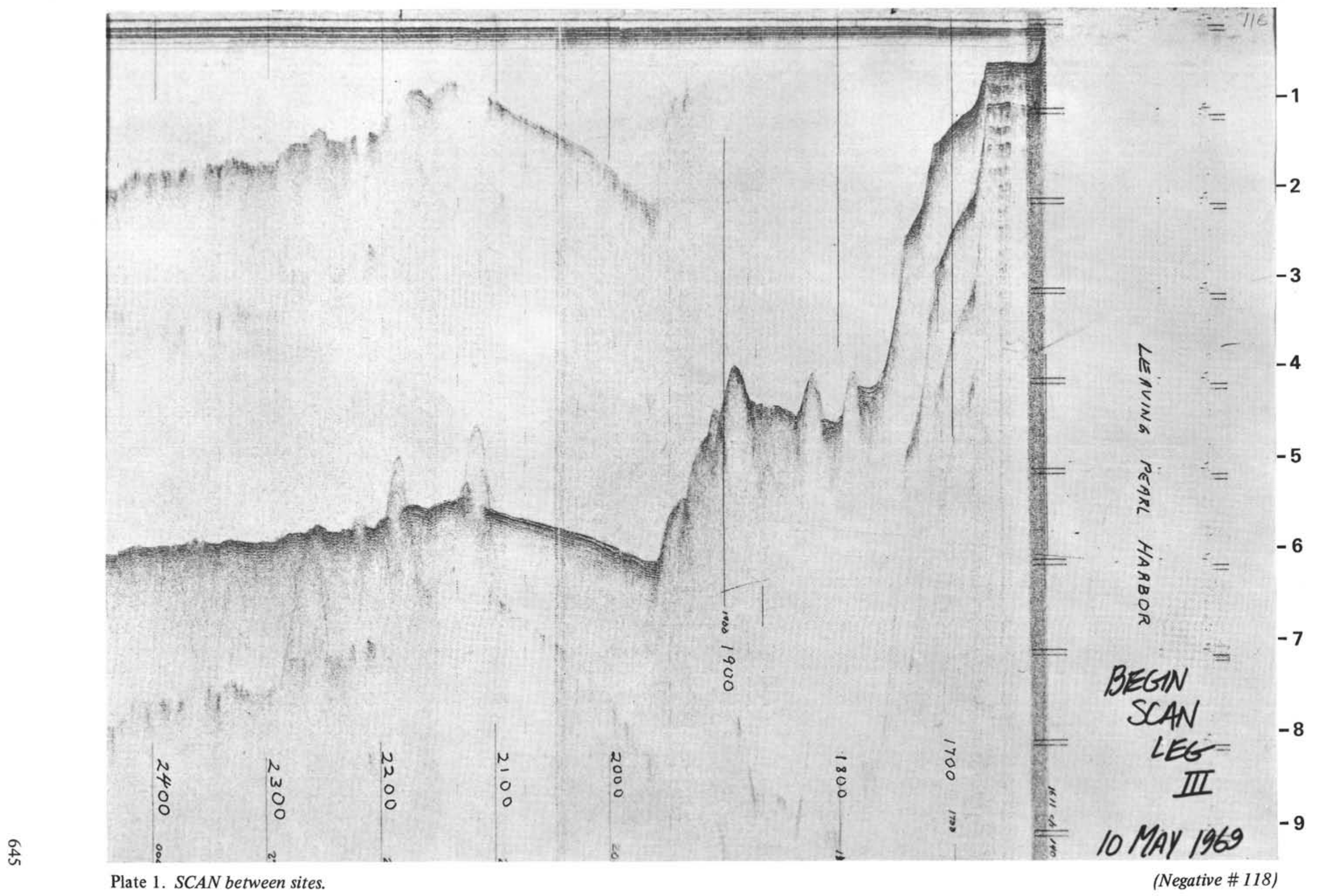



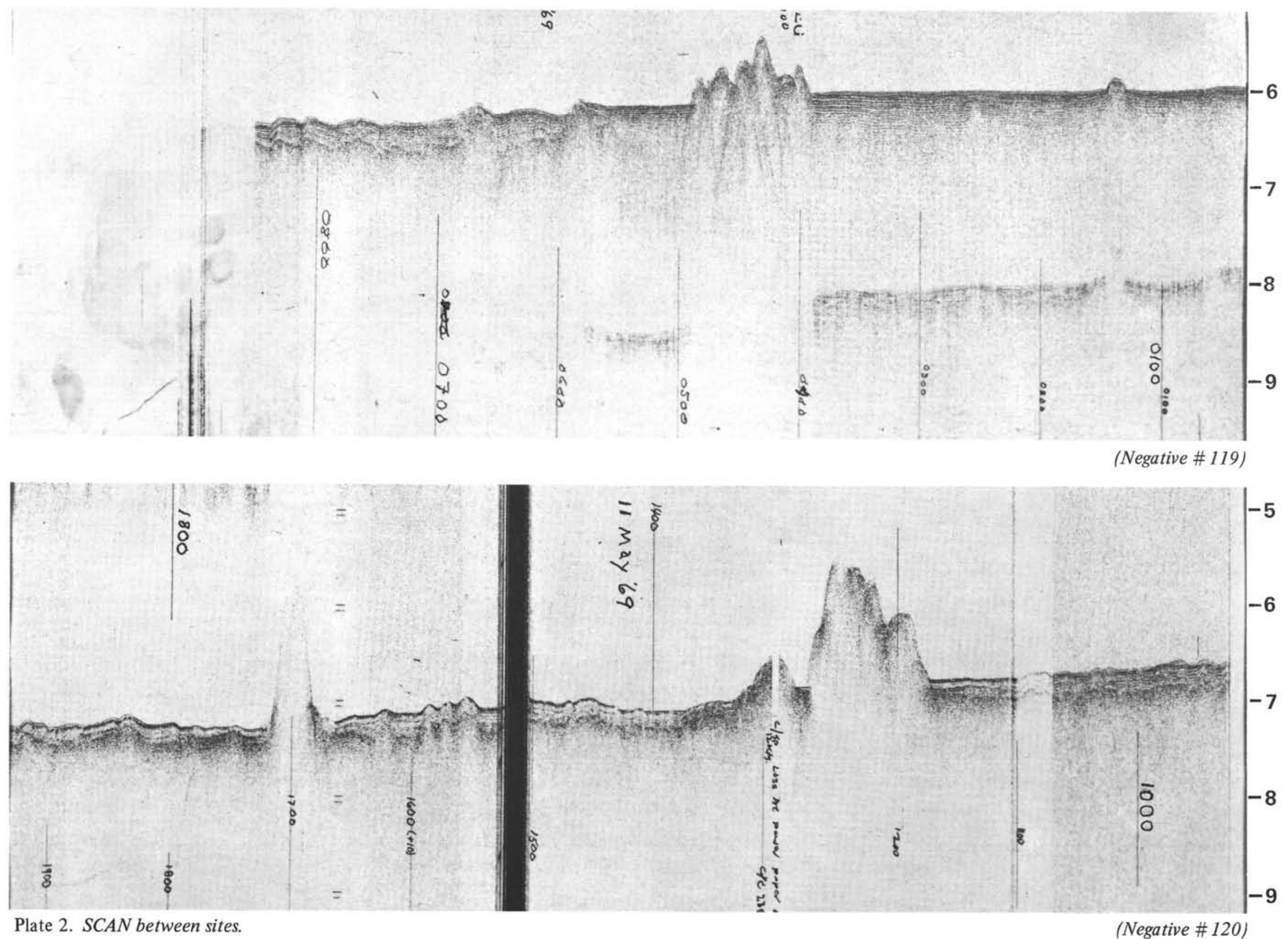


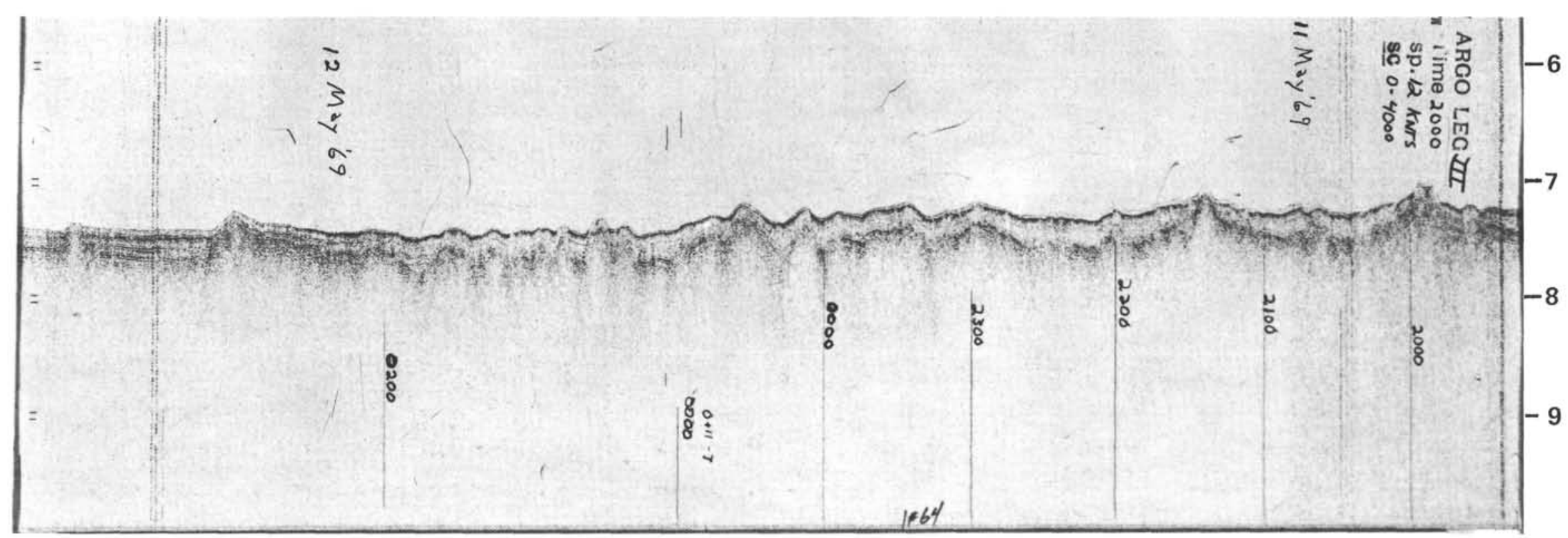

(Negative \# 121)

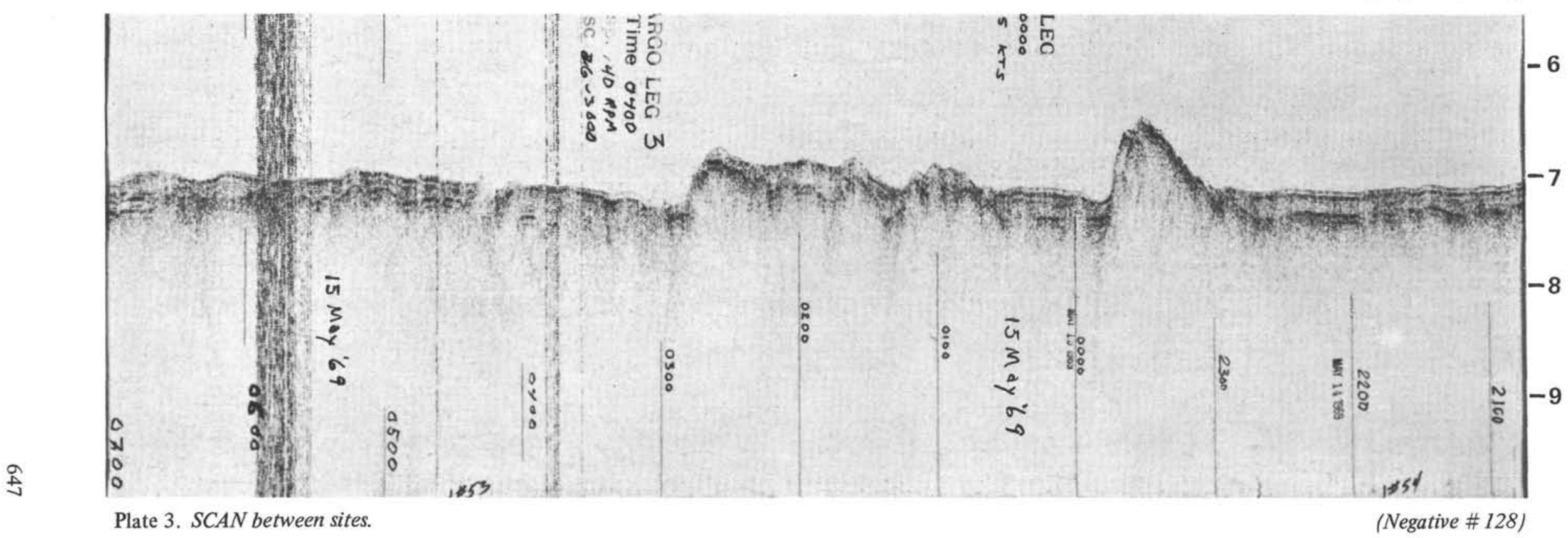




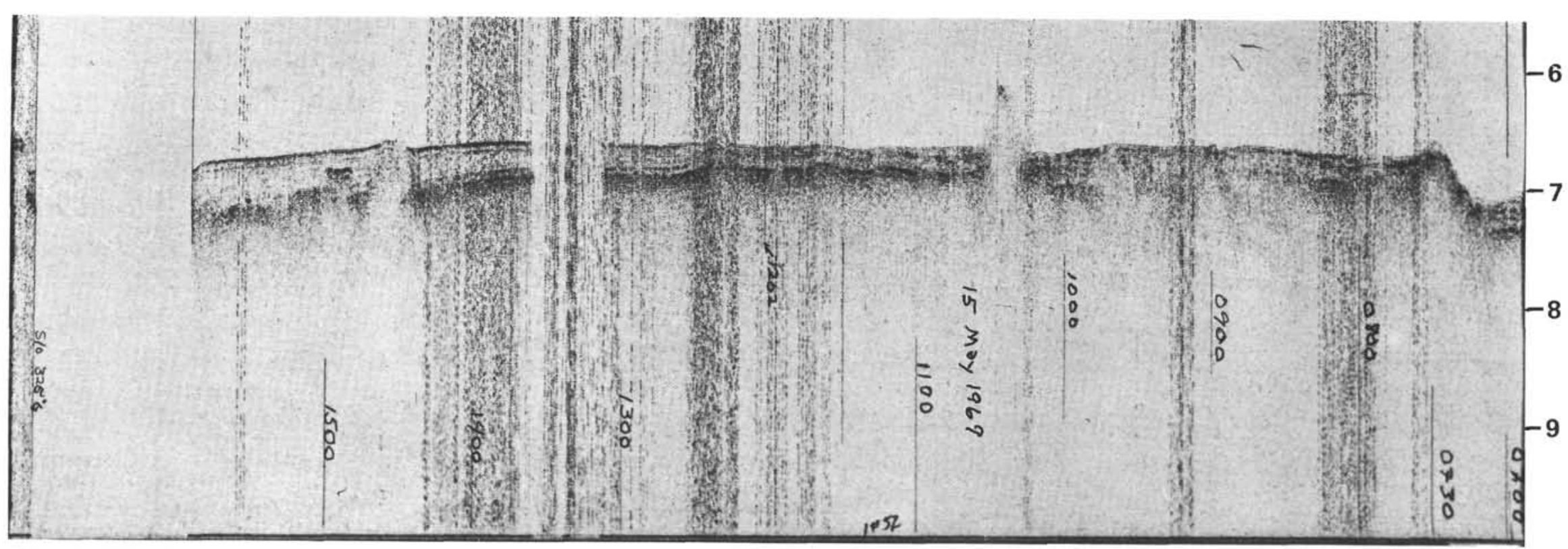

Plate 4. SCAN between sites.

(Negative \# 129) 


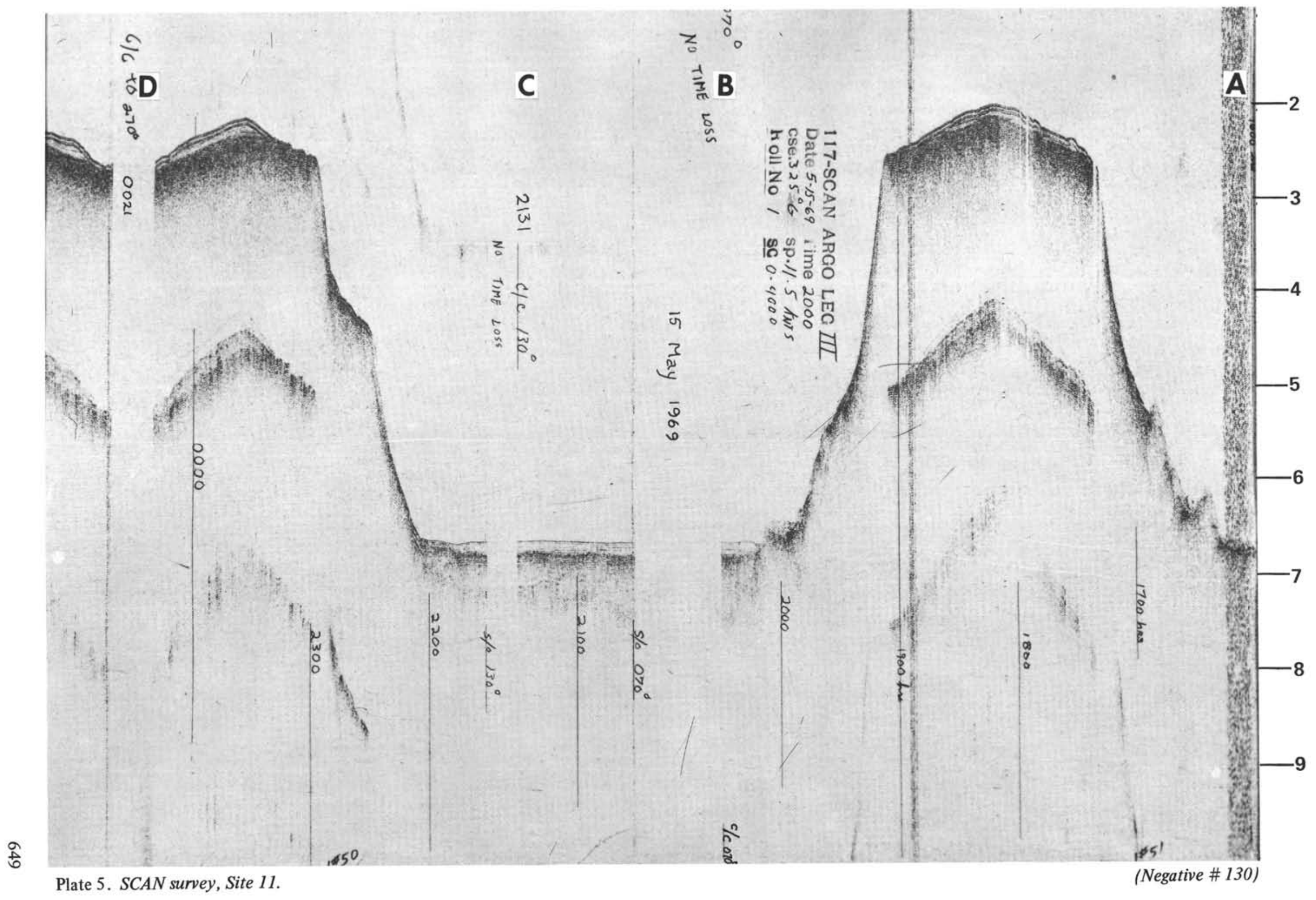



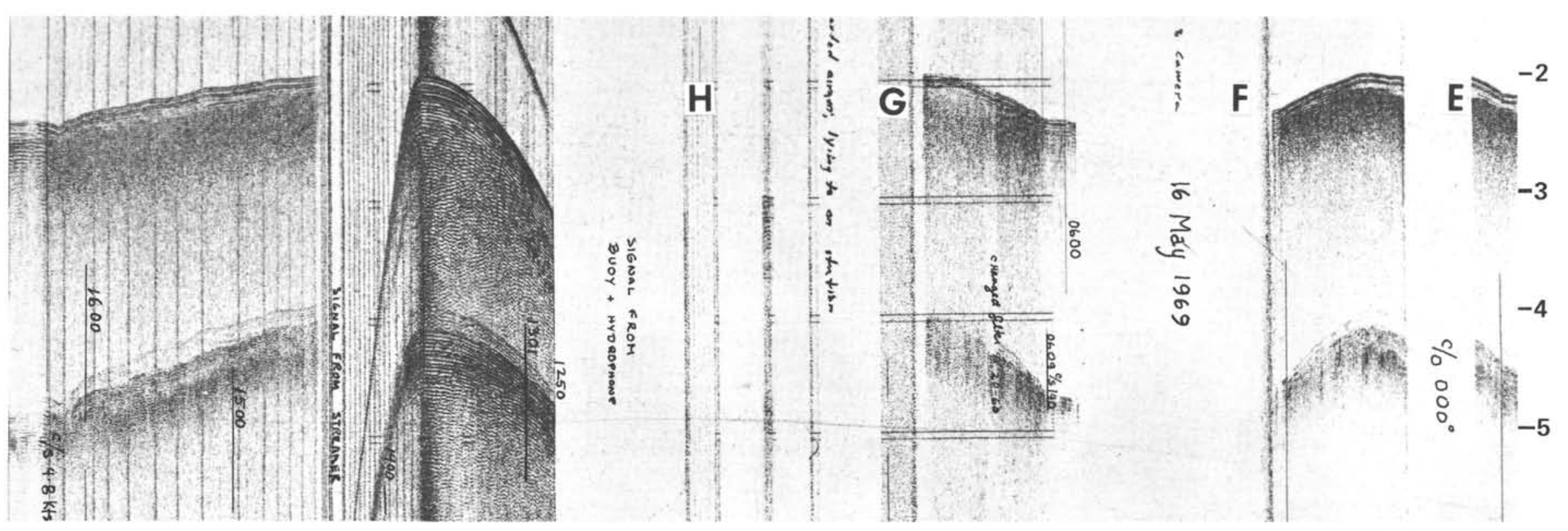

(Negative \# 131)
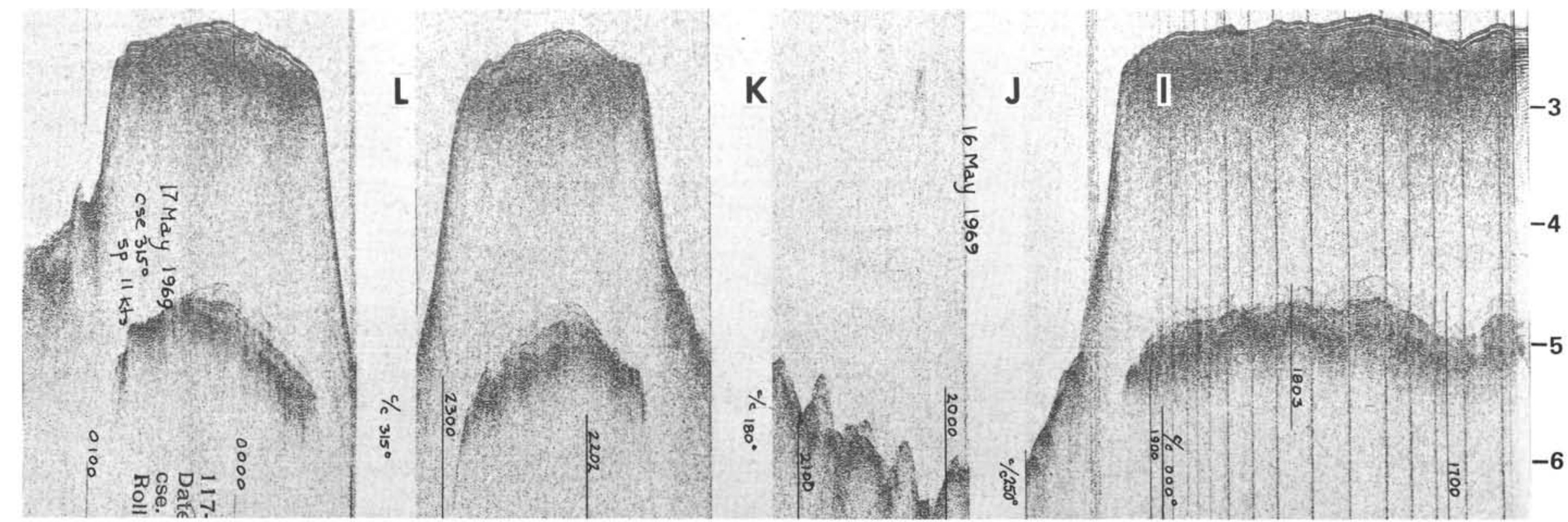

Plate 6. SCAN survey, Site 11. 

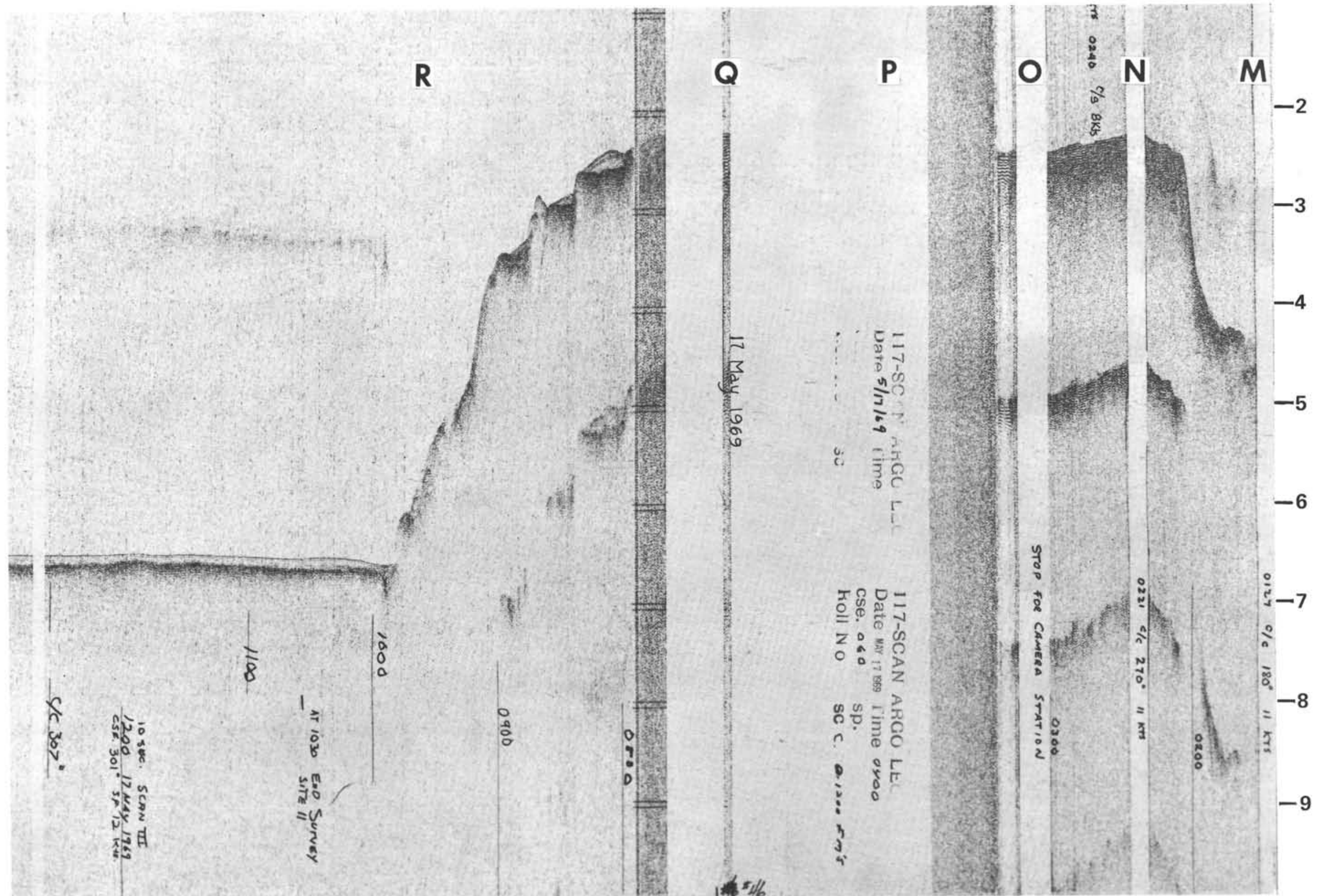

Plate 7. SCAN survey, Site 11. 
बे
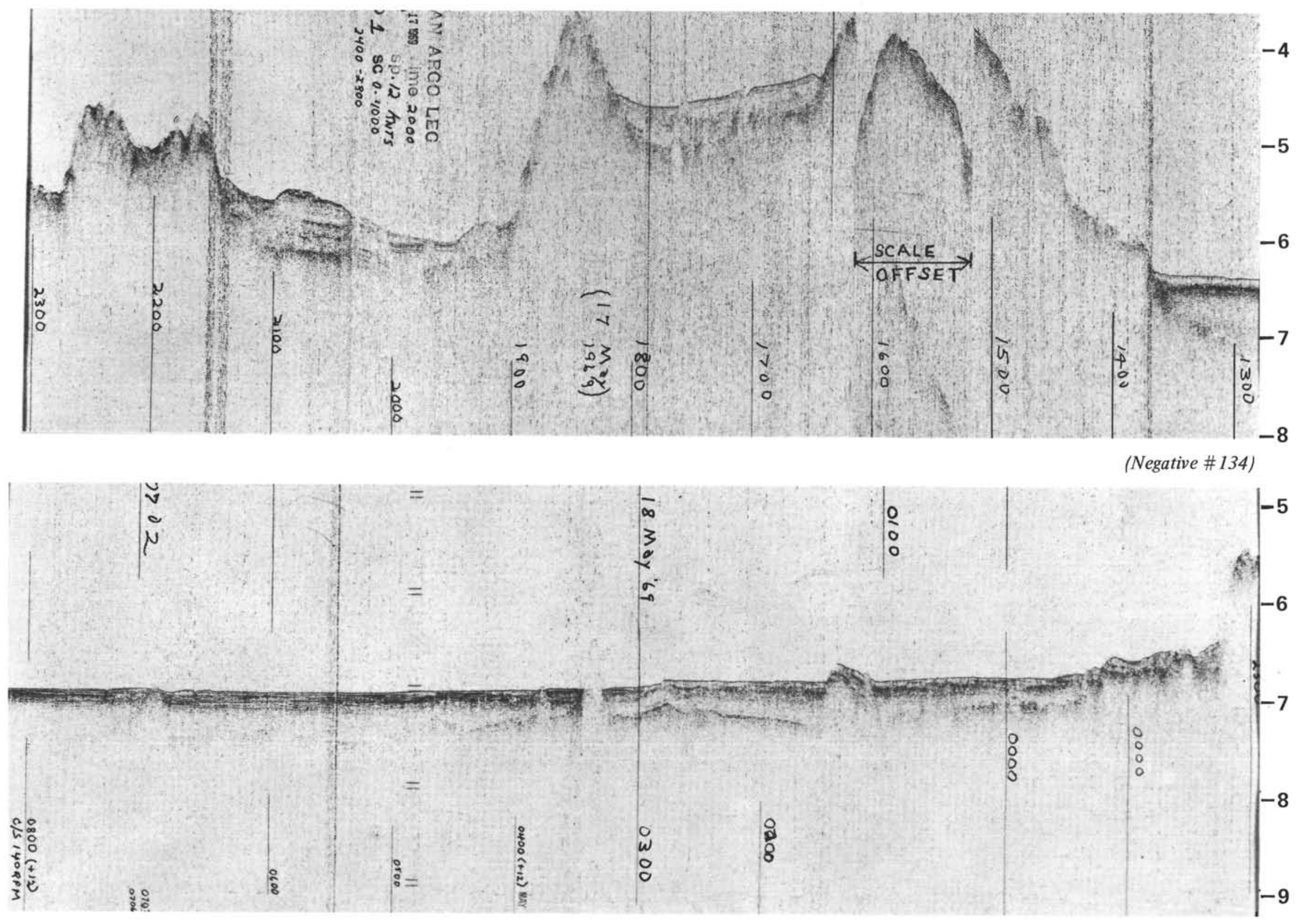

Plate 8. SCAN between sites.

(Negative \#135) 

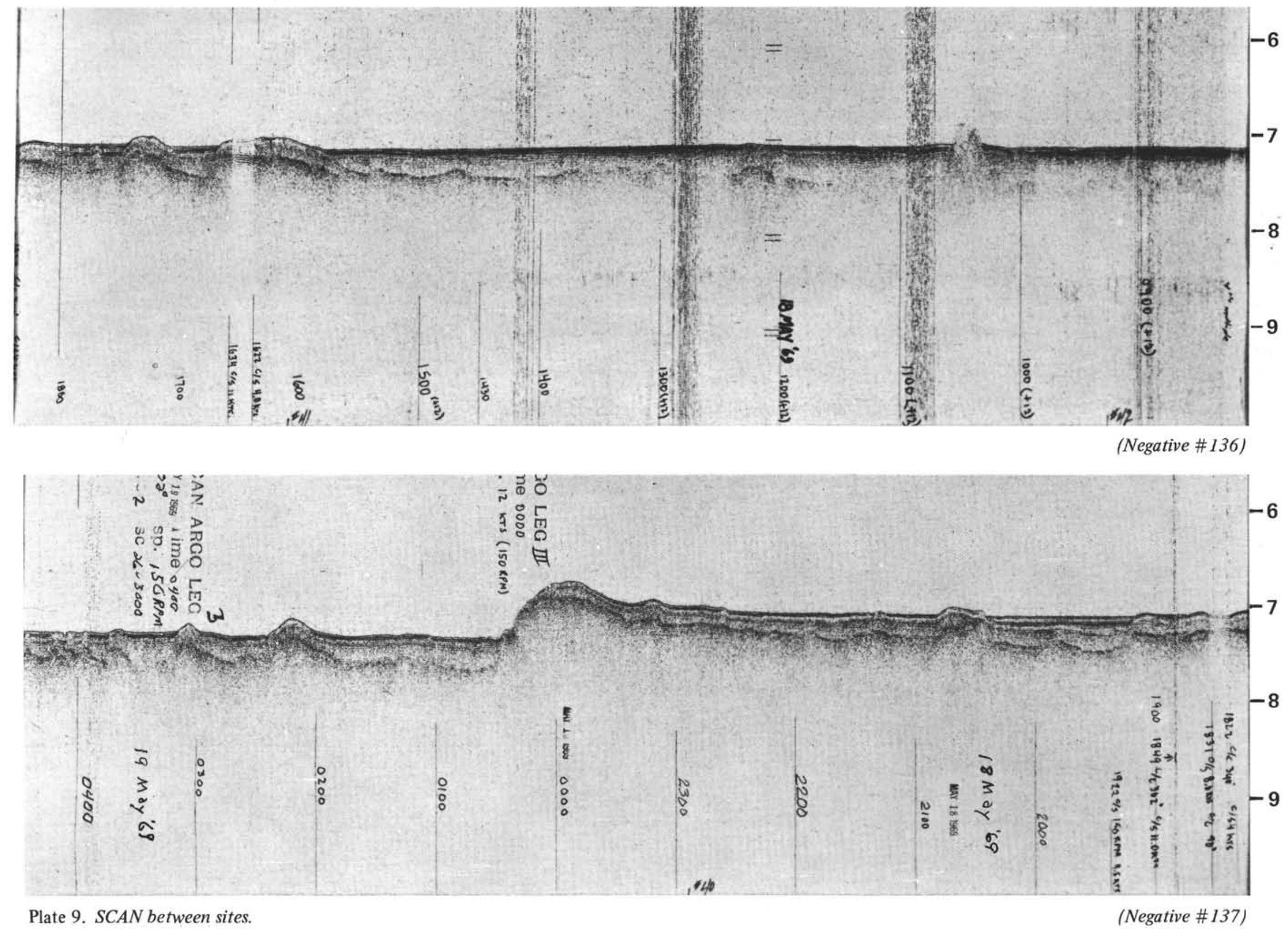

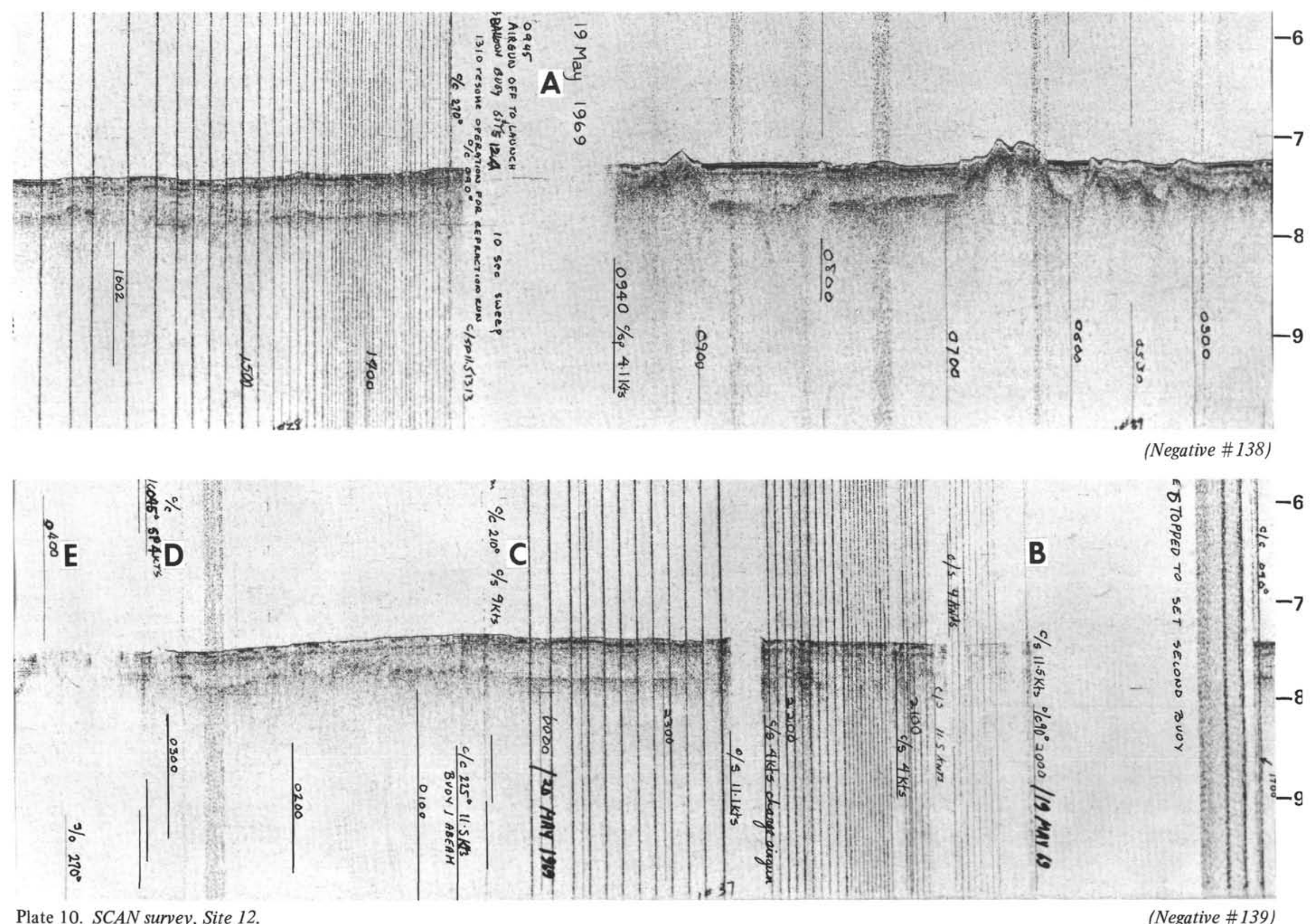

Plate 10. SCAN survey, Site 12. 

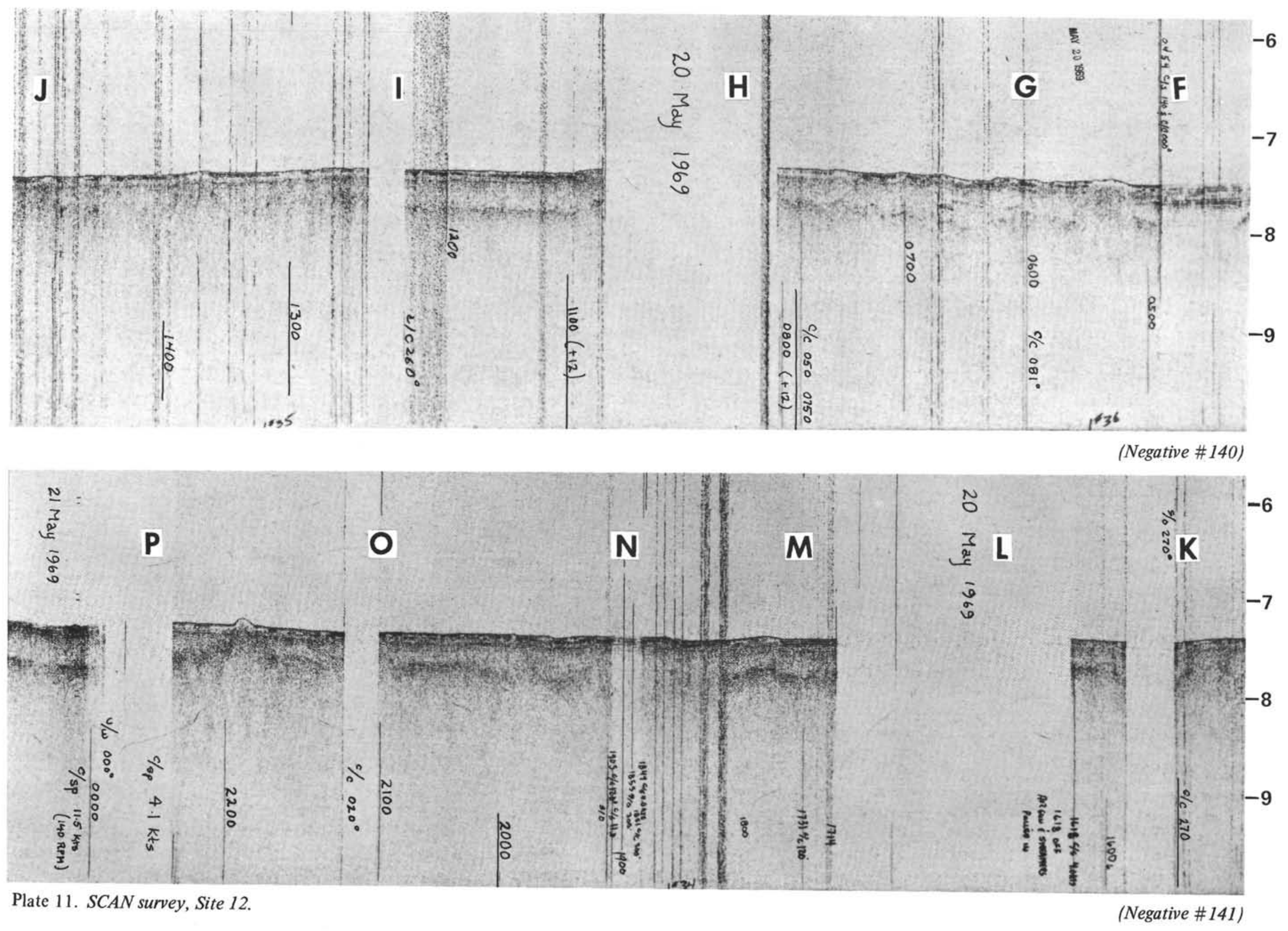


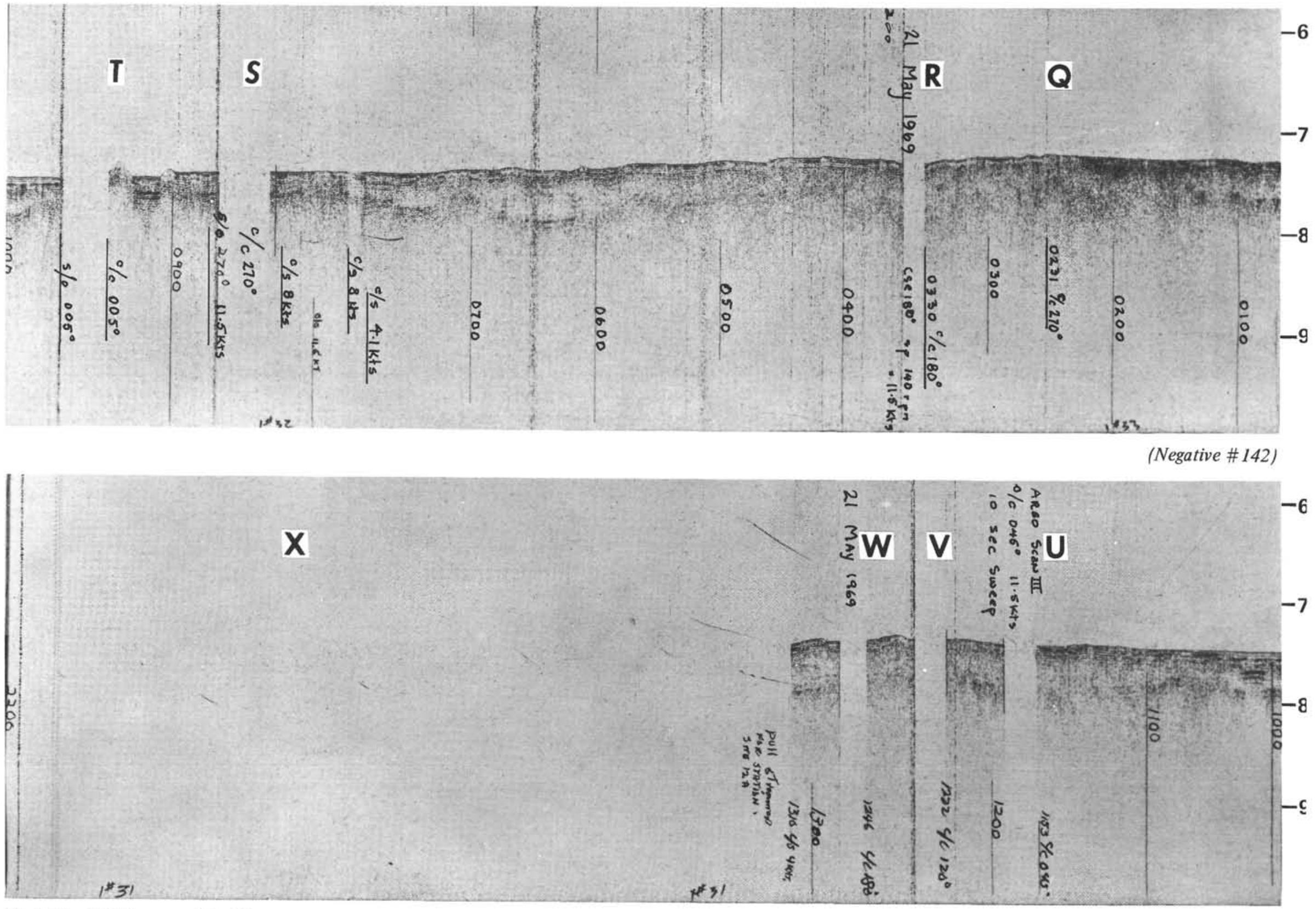




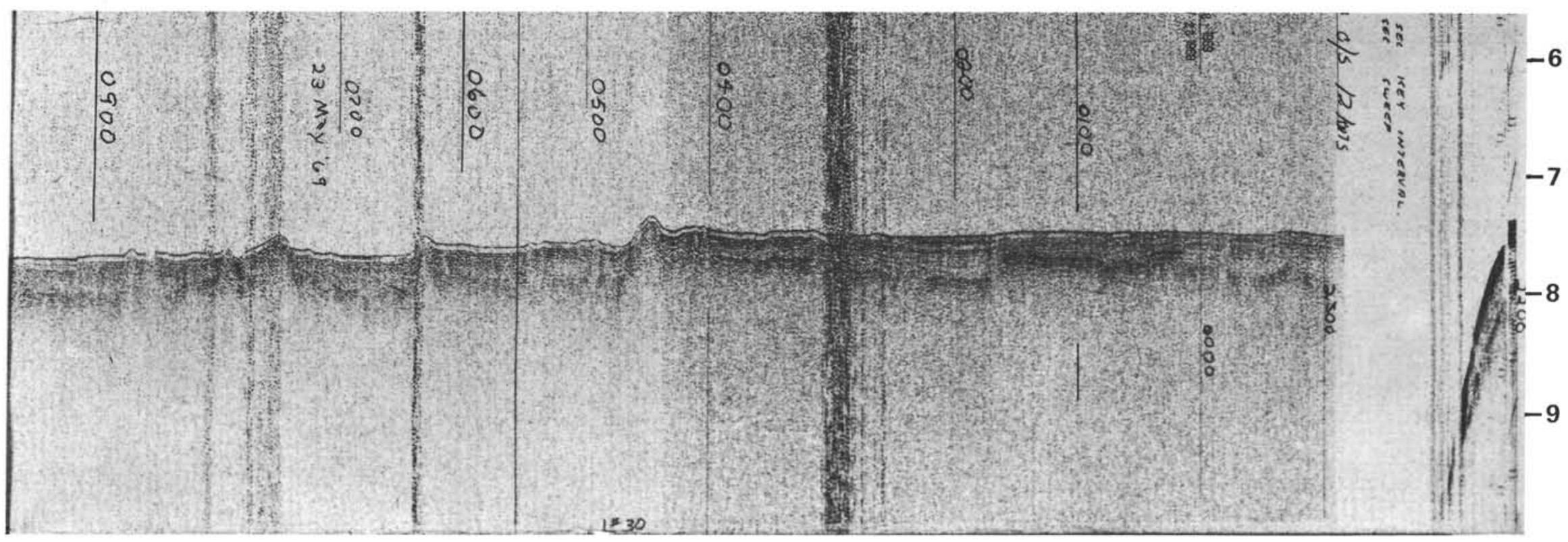

(Negative \#144)

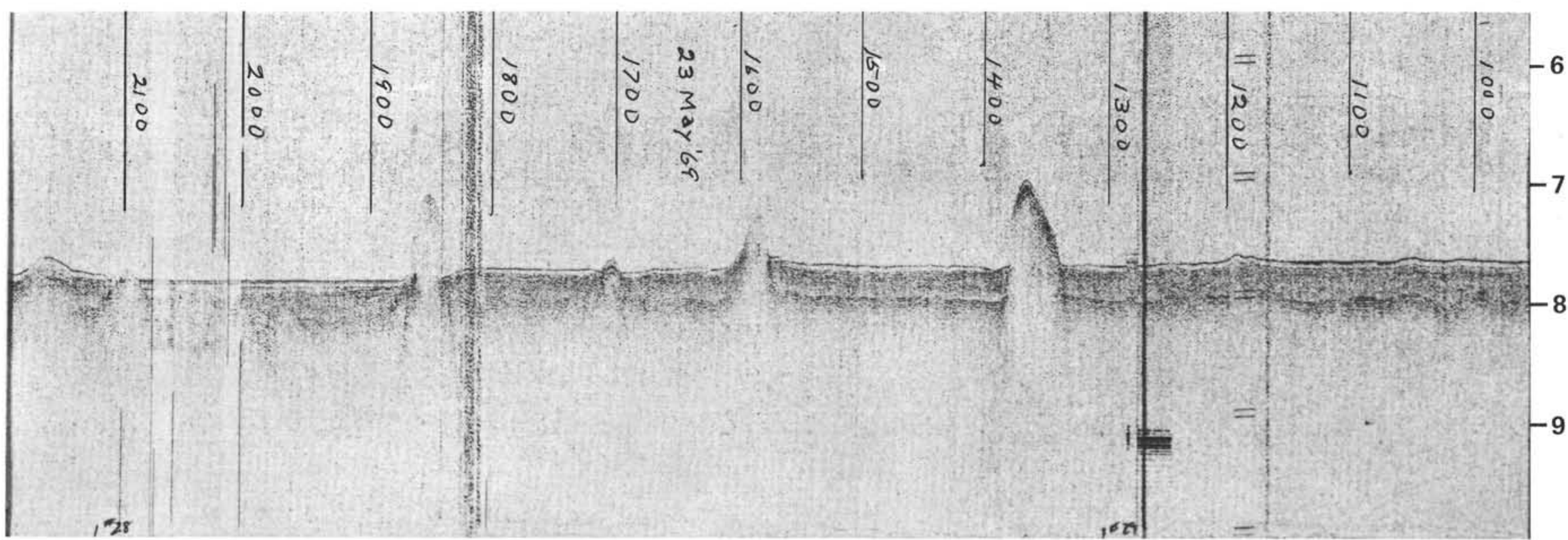

Plate 13. SCAN between sites. 


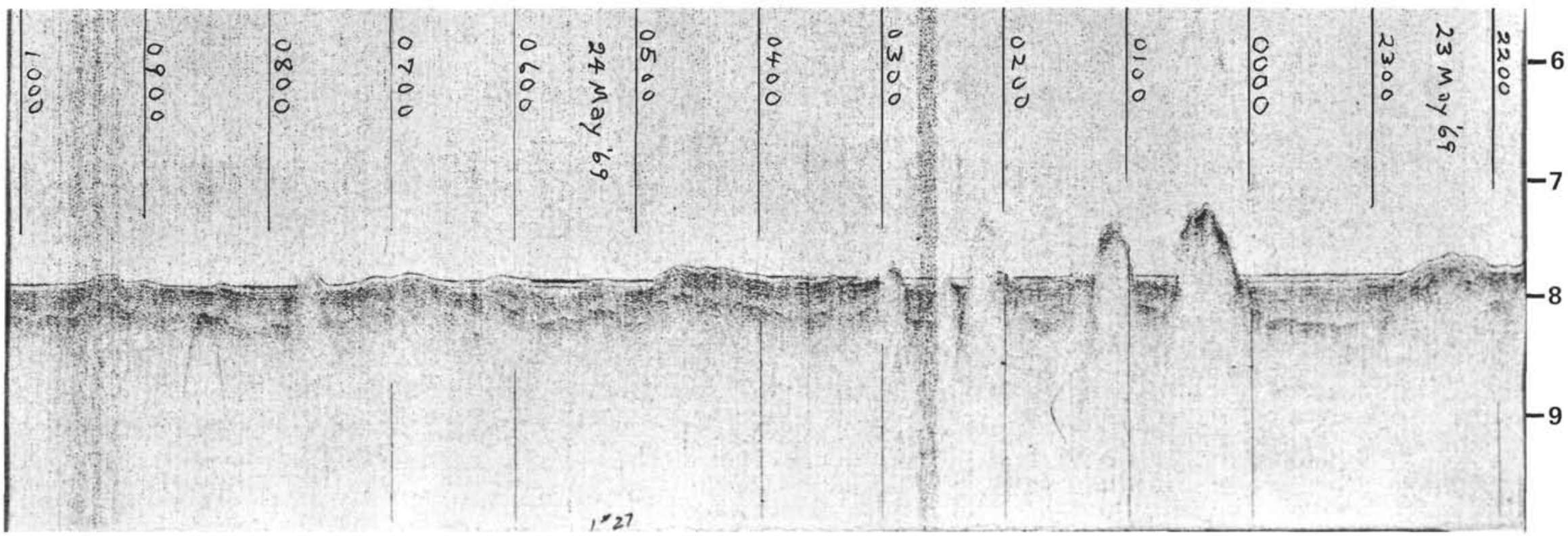

(Negative \#146)

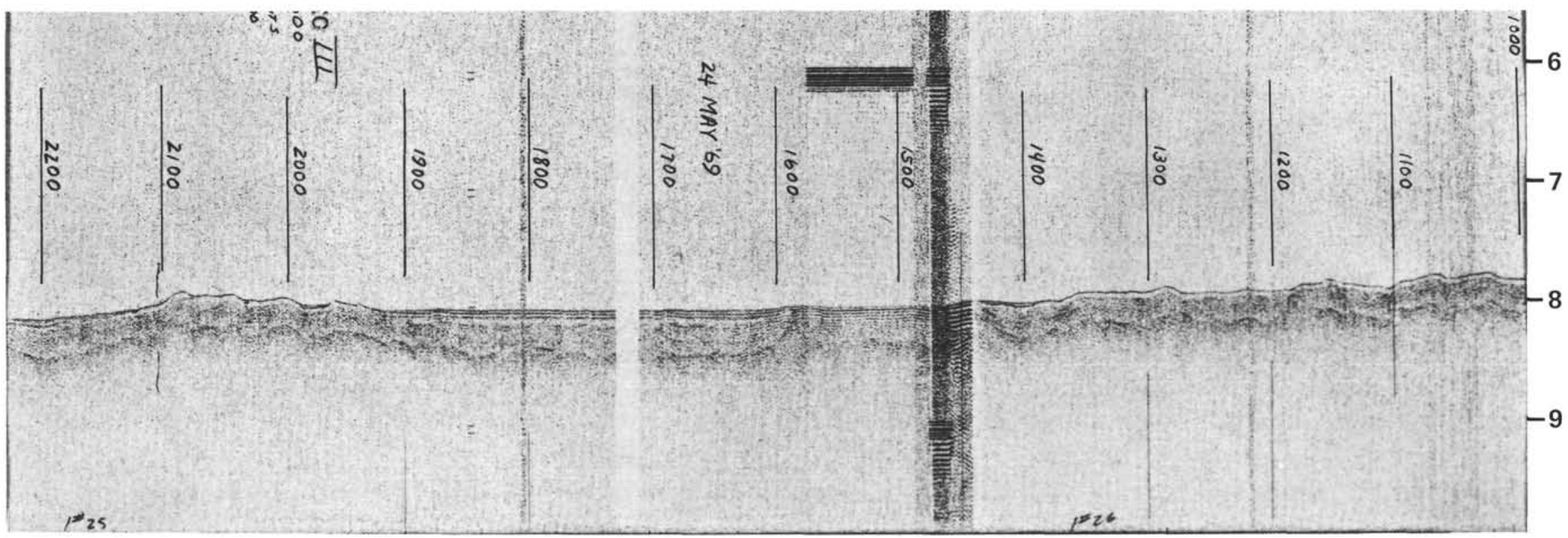




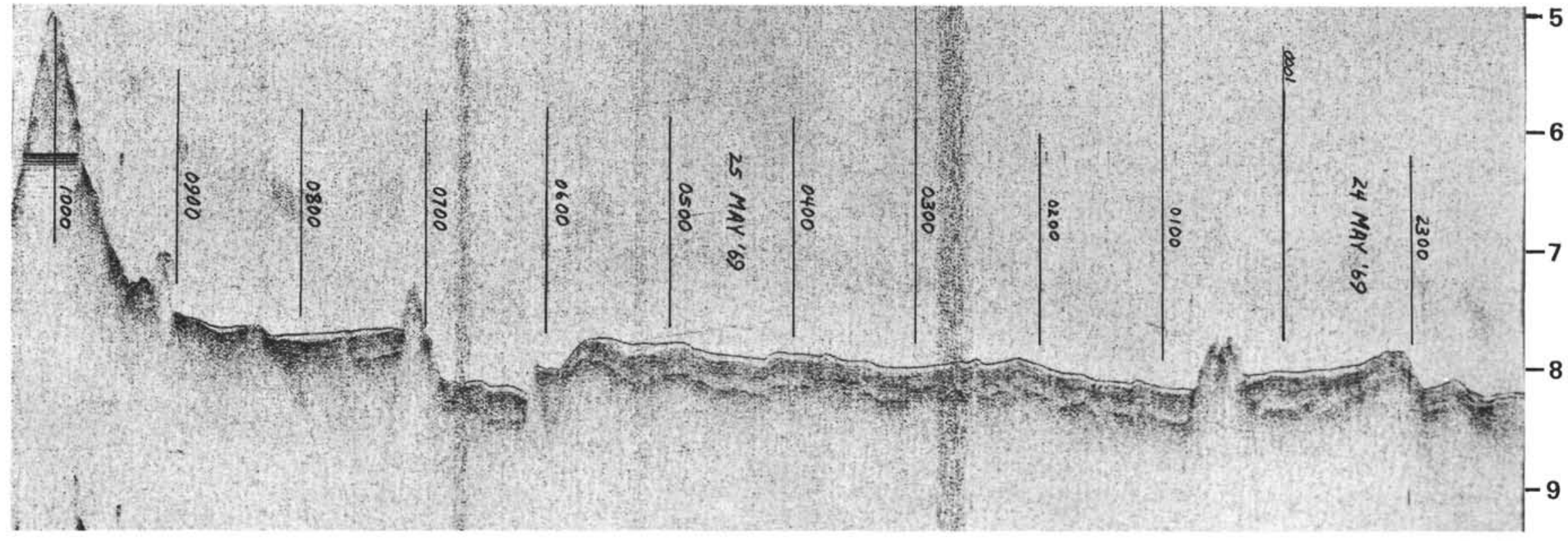

(Negative \#148)

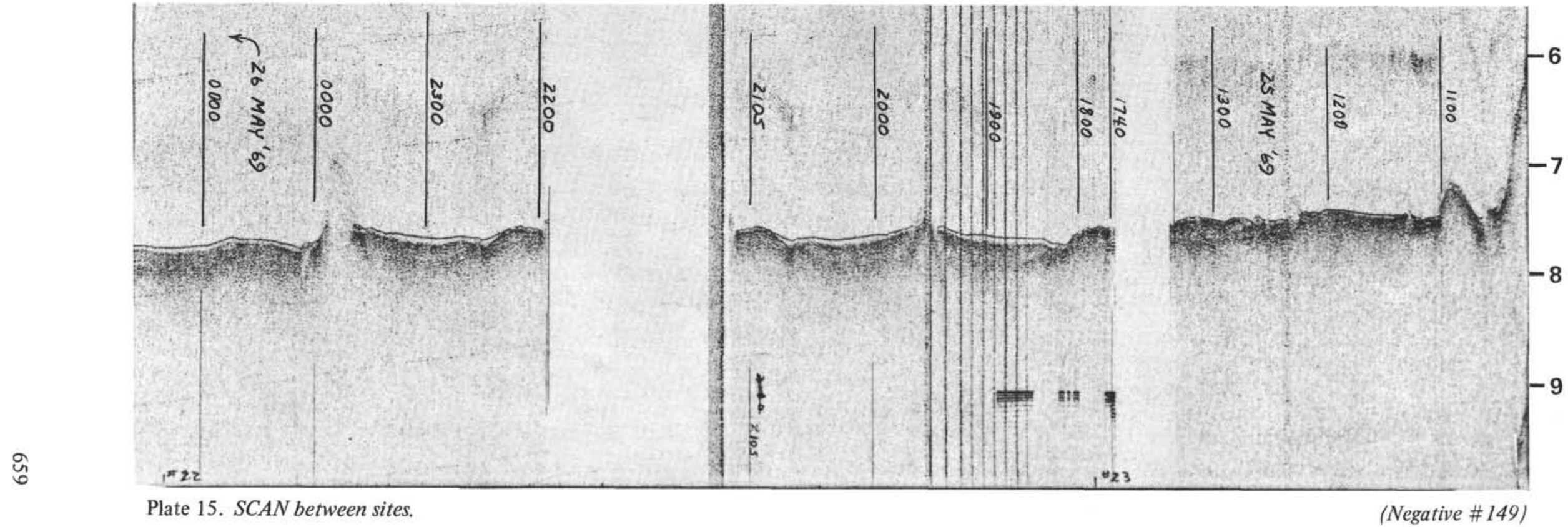




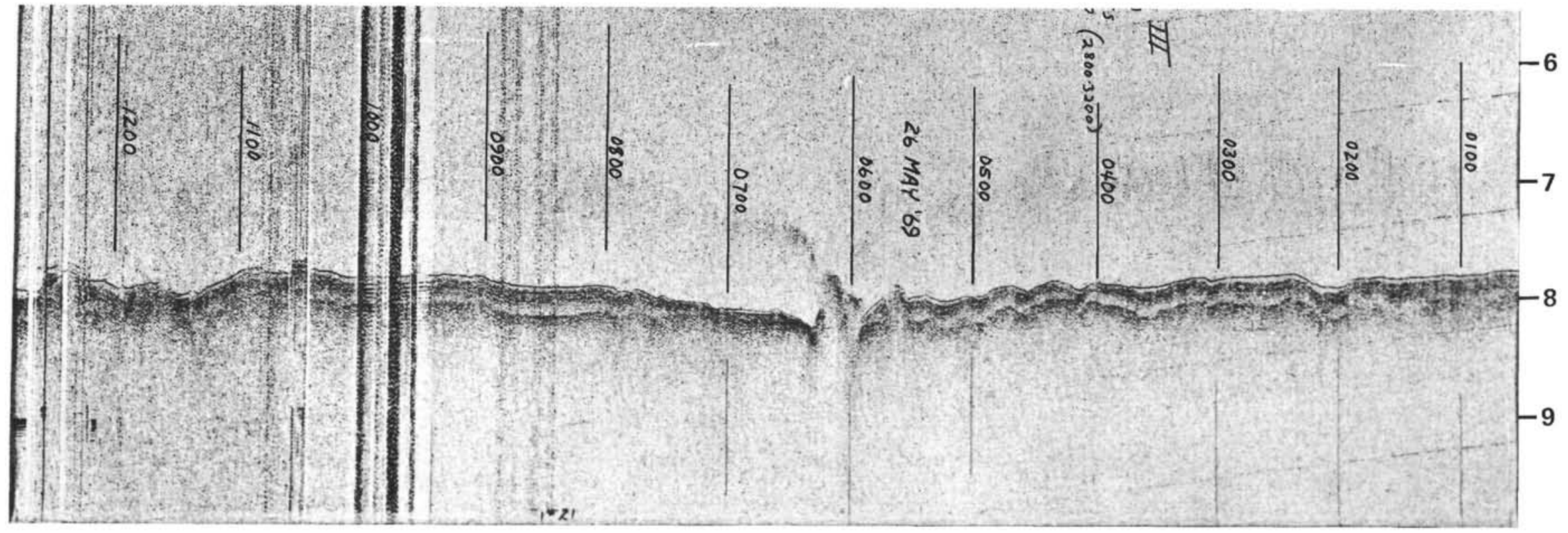

(Negative \#150)

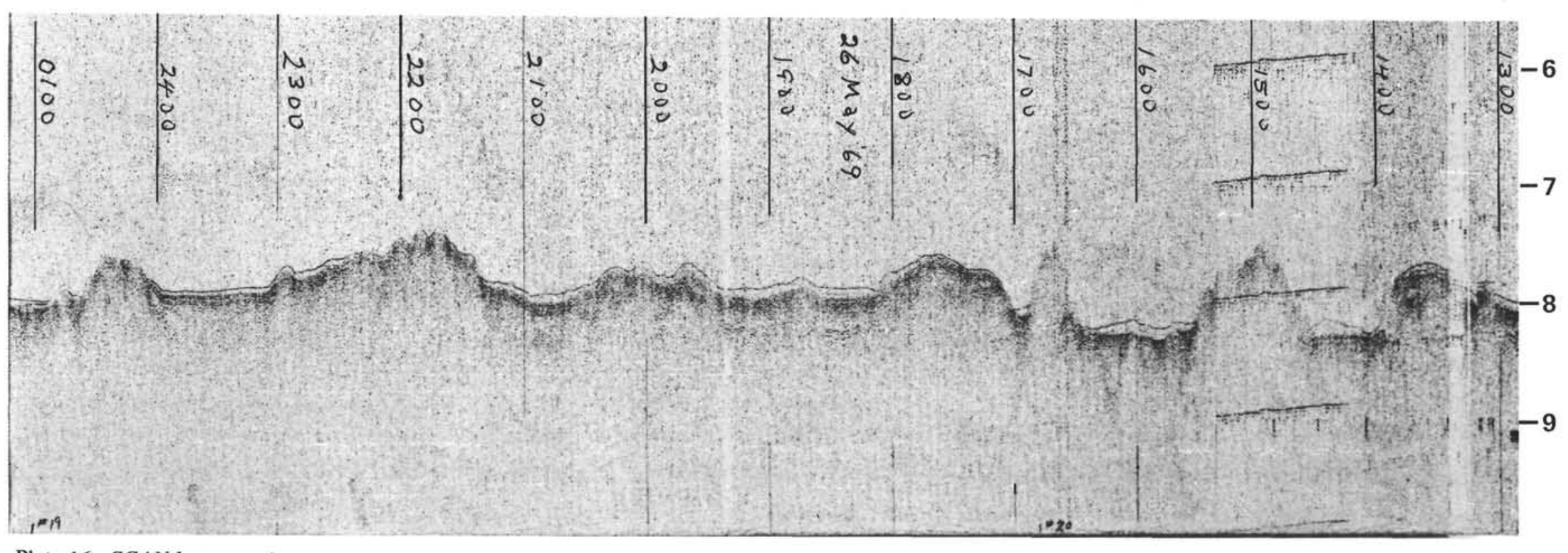




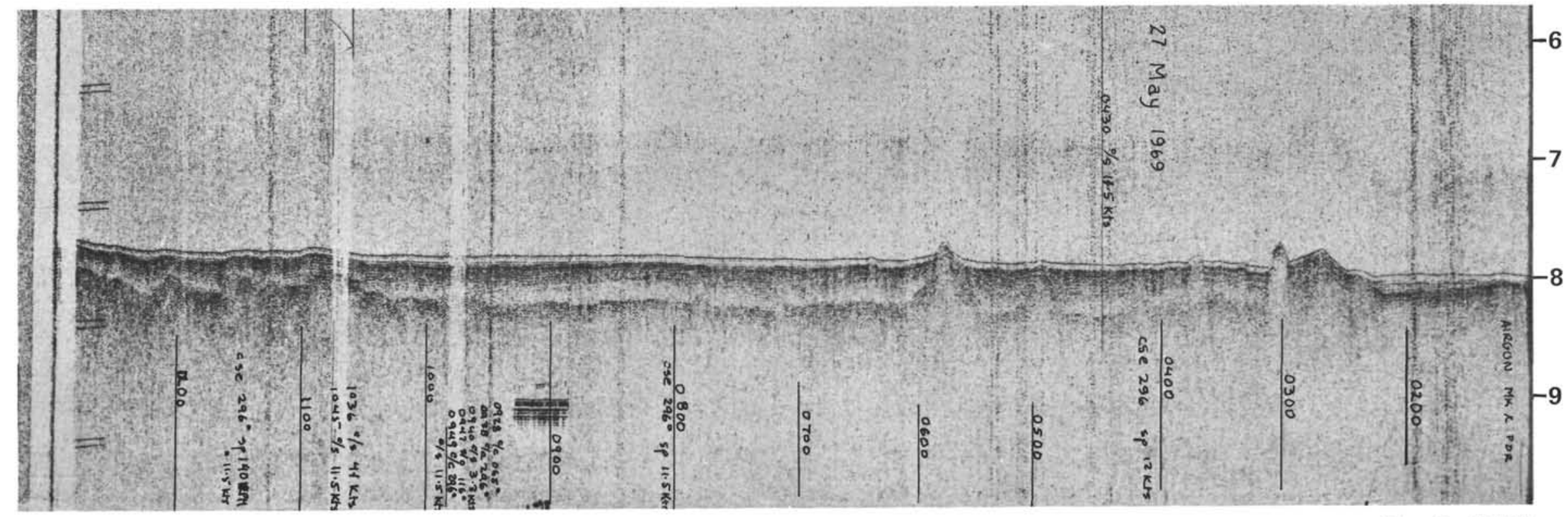

(Negative \#152)

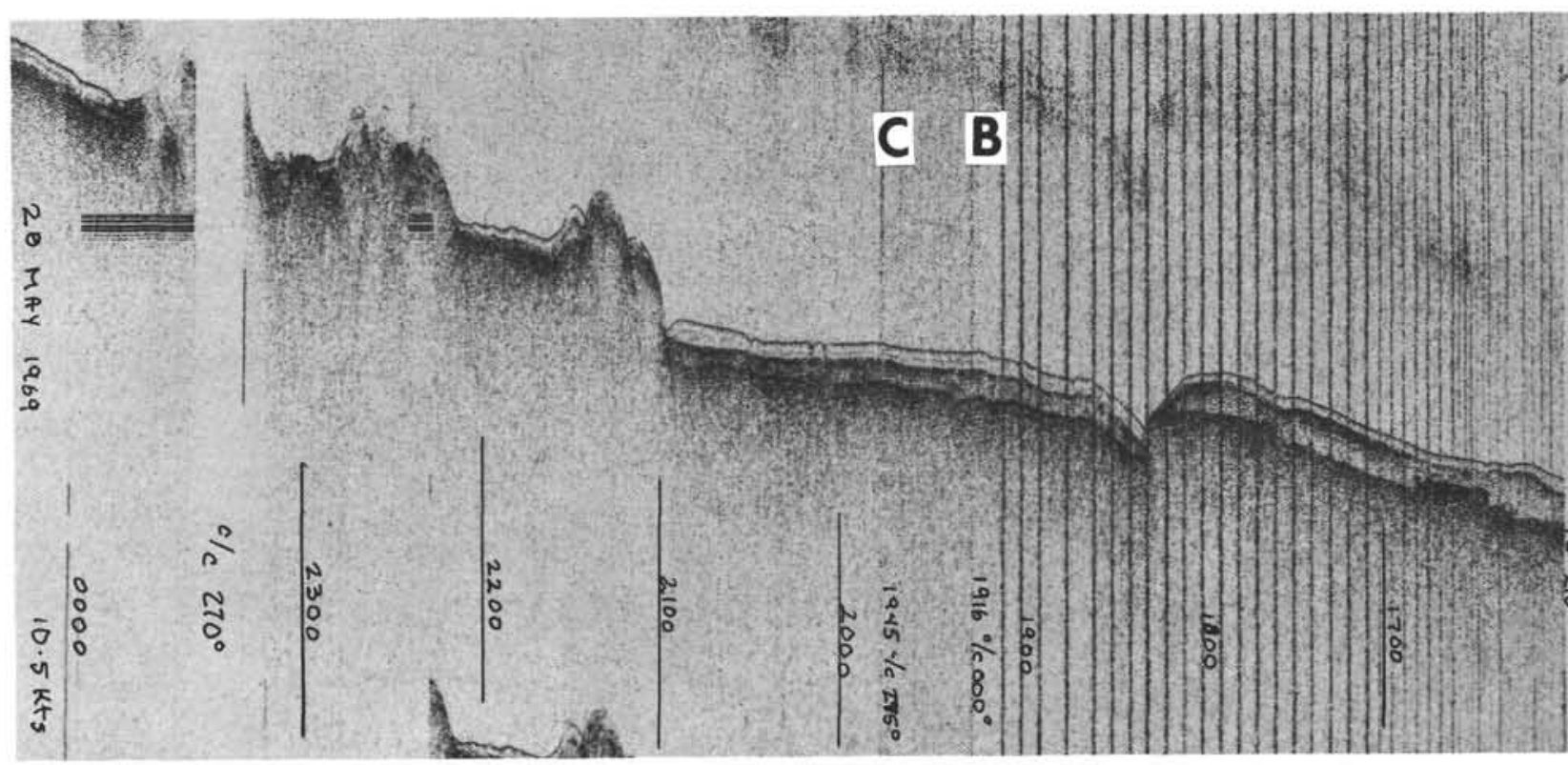

Plate 17. SCAN survey, Sites 13 and 14.

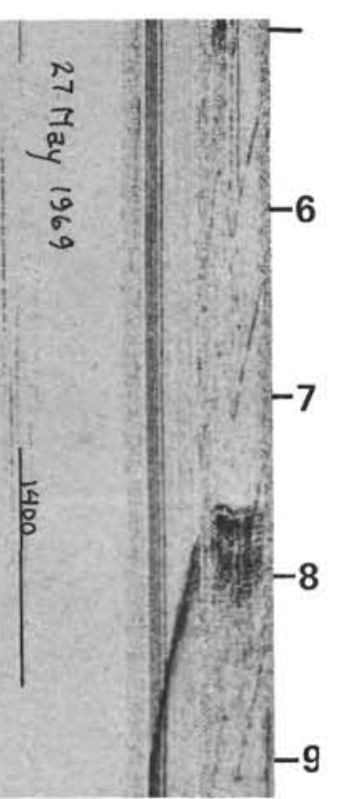

(Negative \#153) 

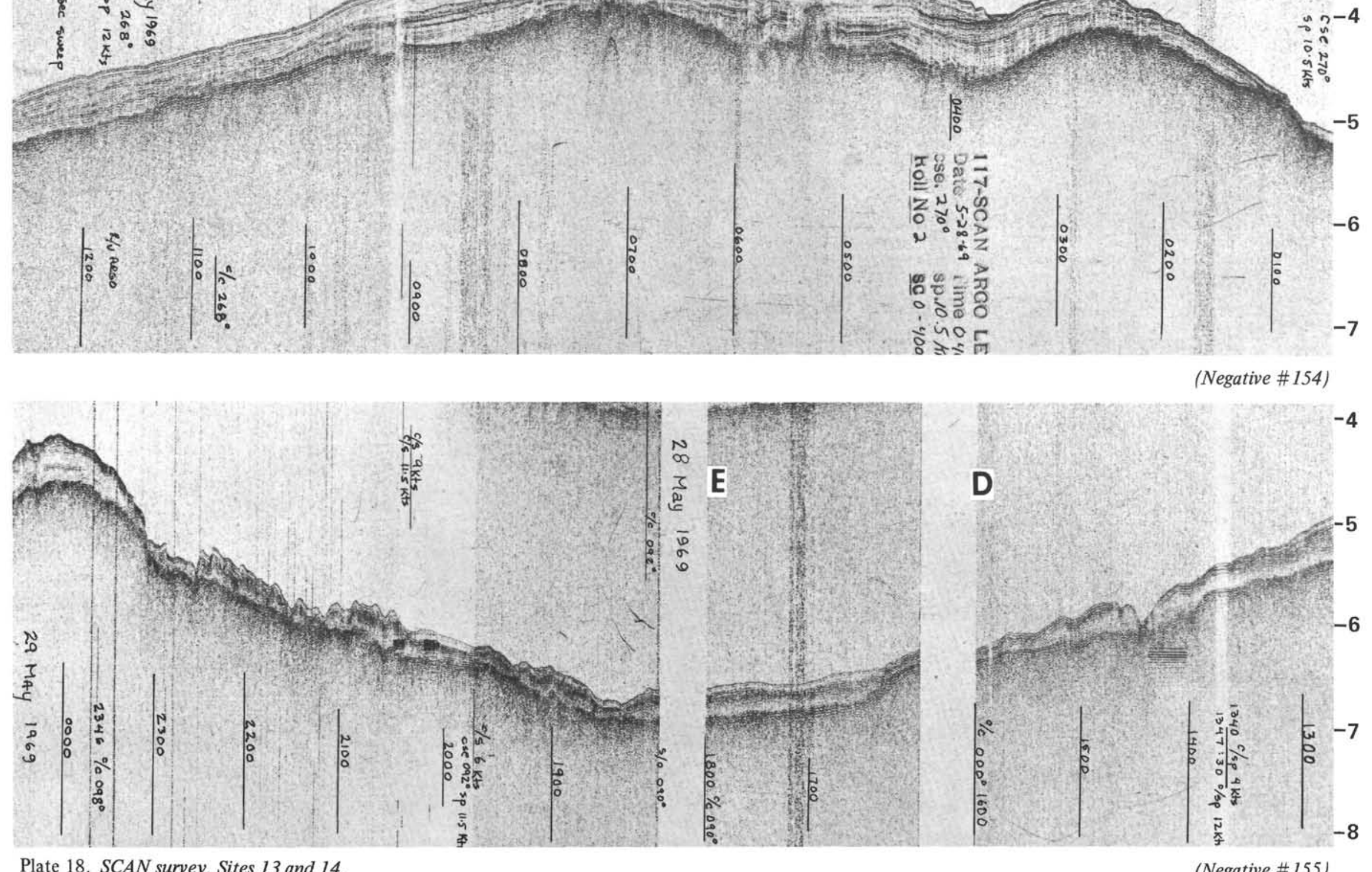

Plate 18. SCAN survey, Sites 13 and 14.

(Negative \#155) 

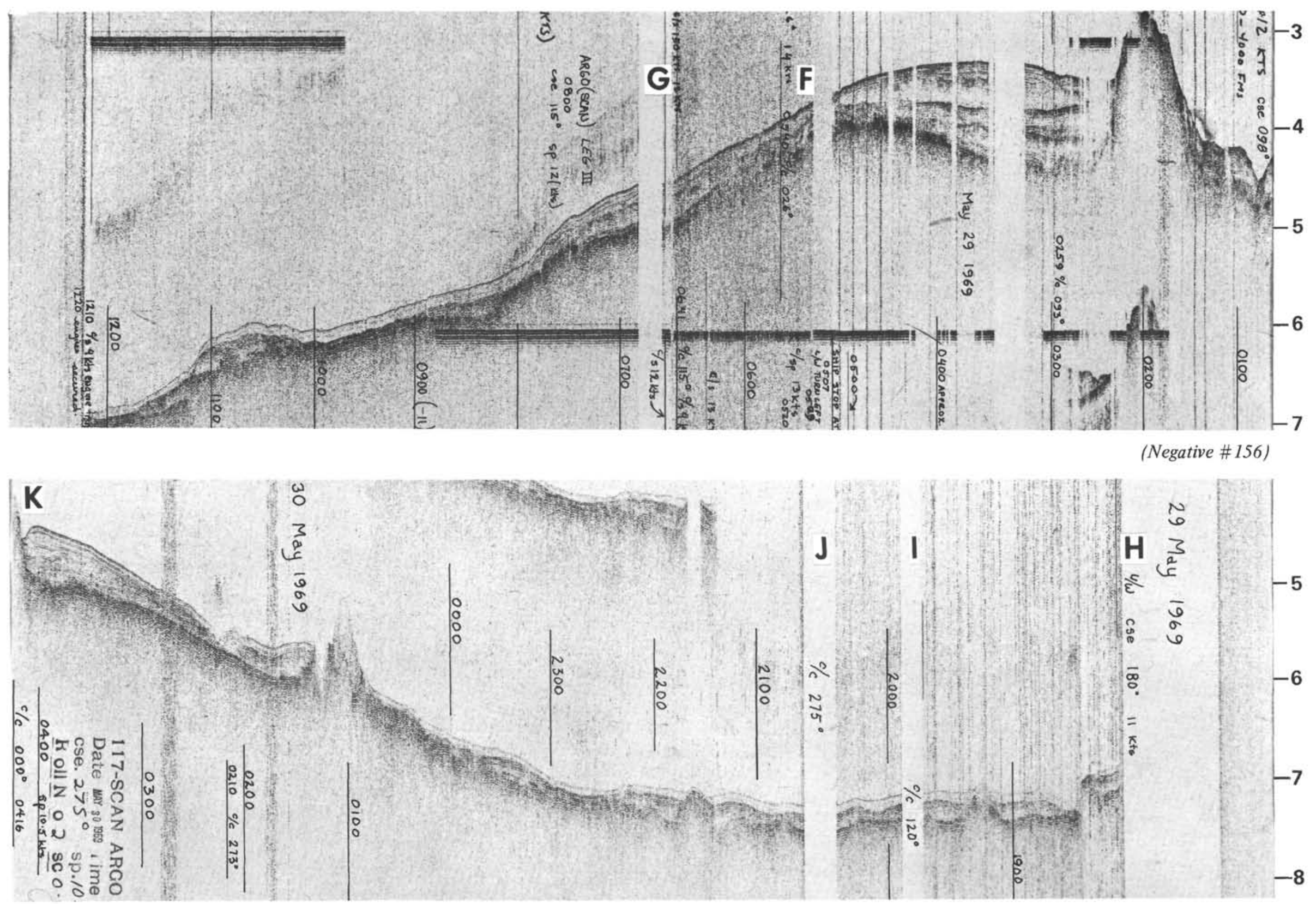

Plate 19. SCAN survey, Sites 13 and 14. 

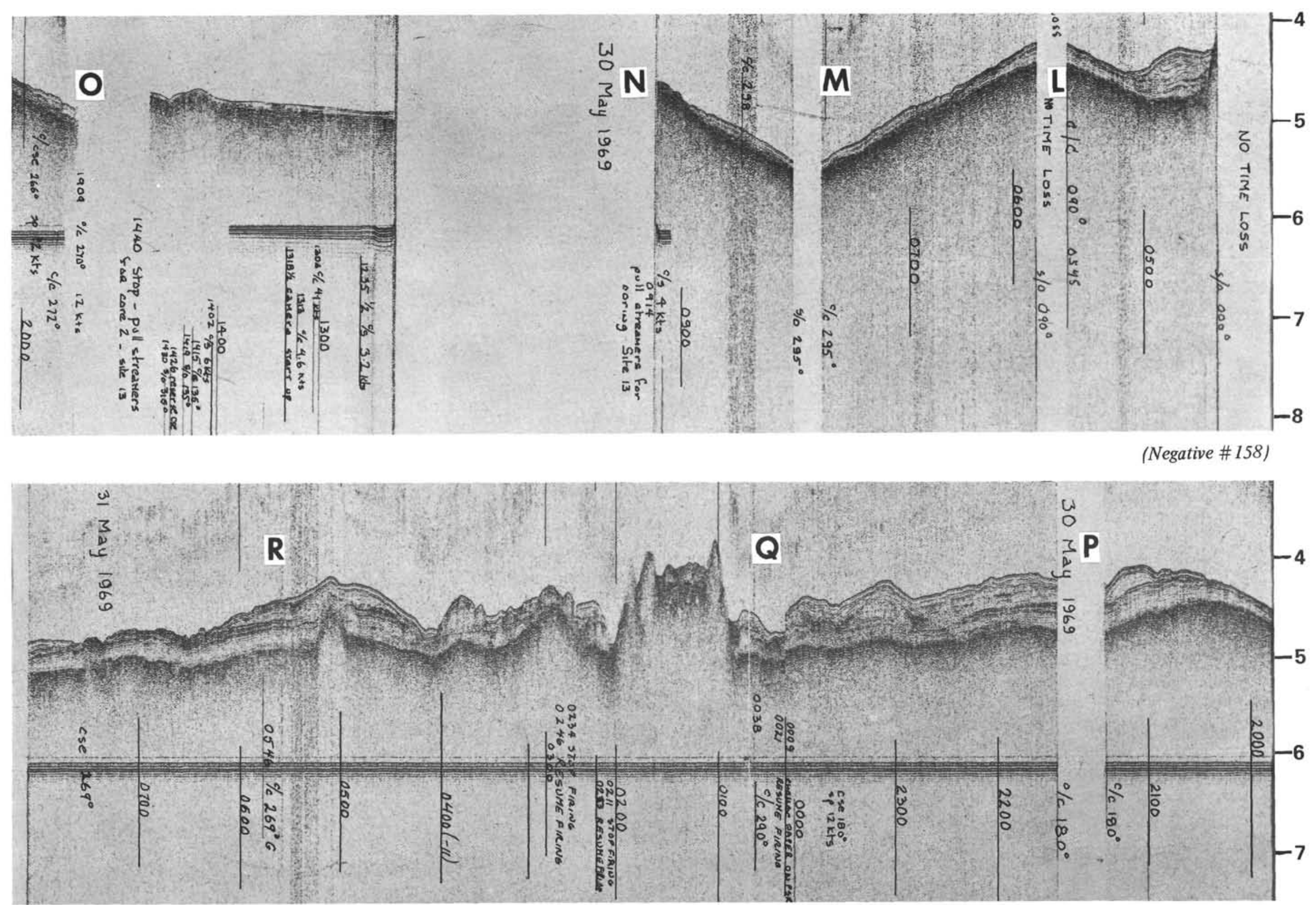


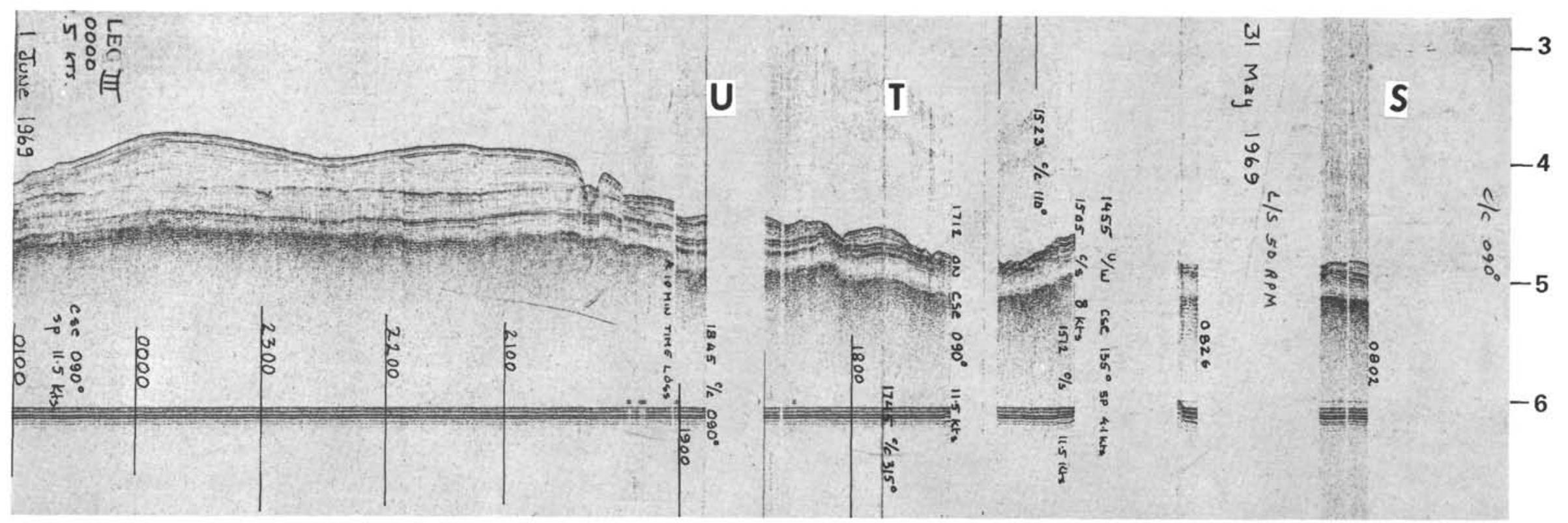

(Negative \#160)

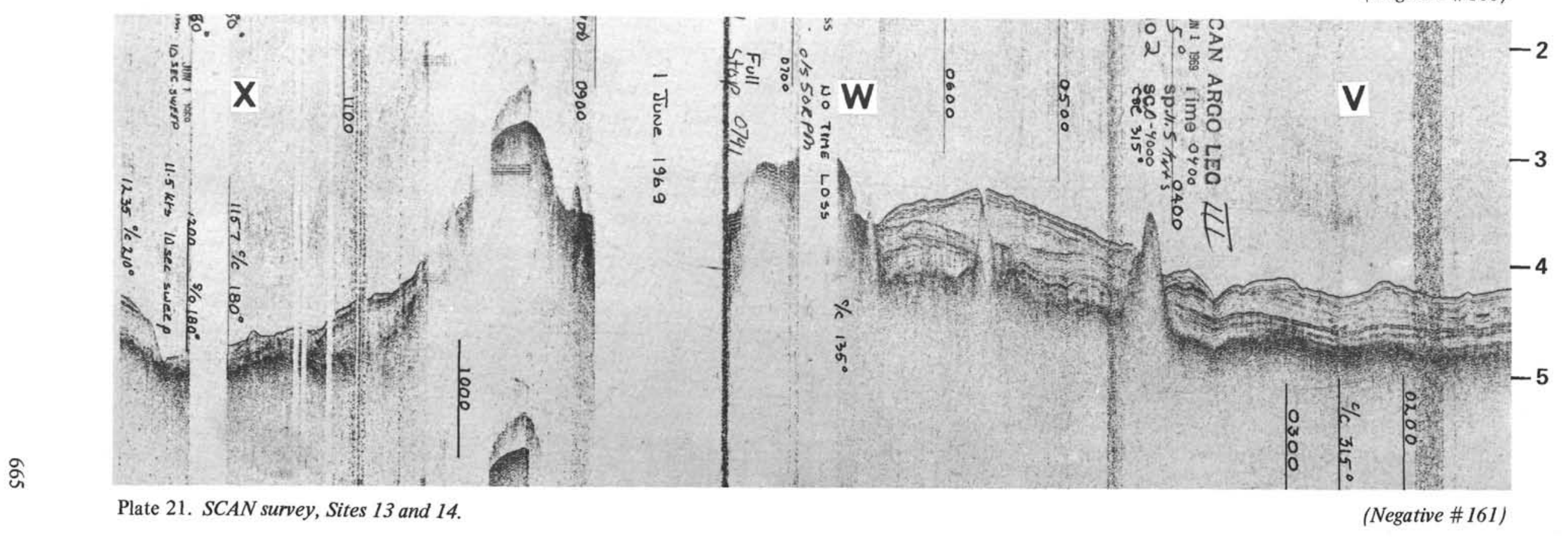



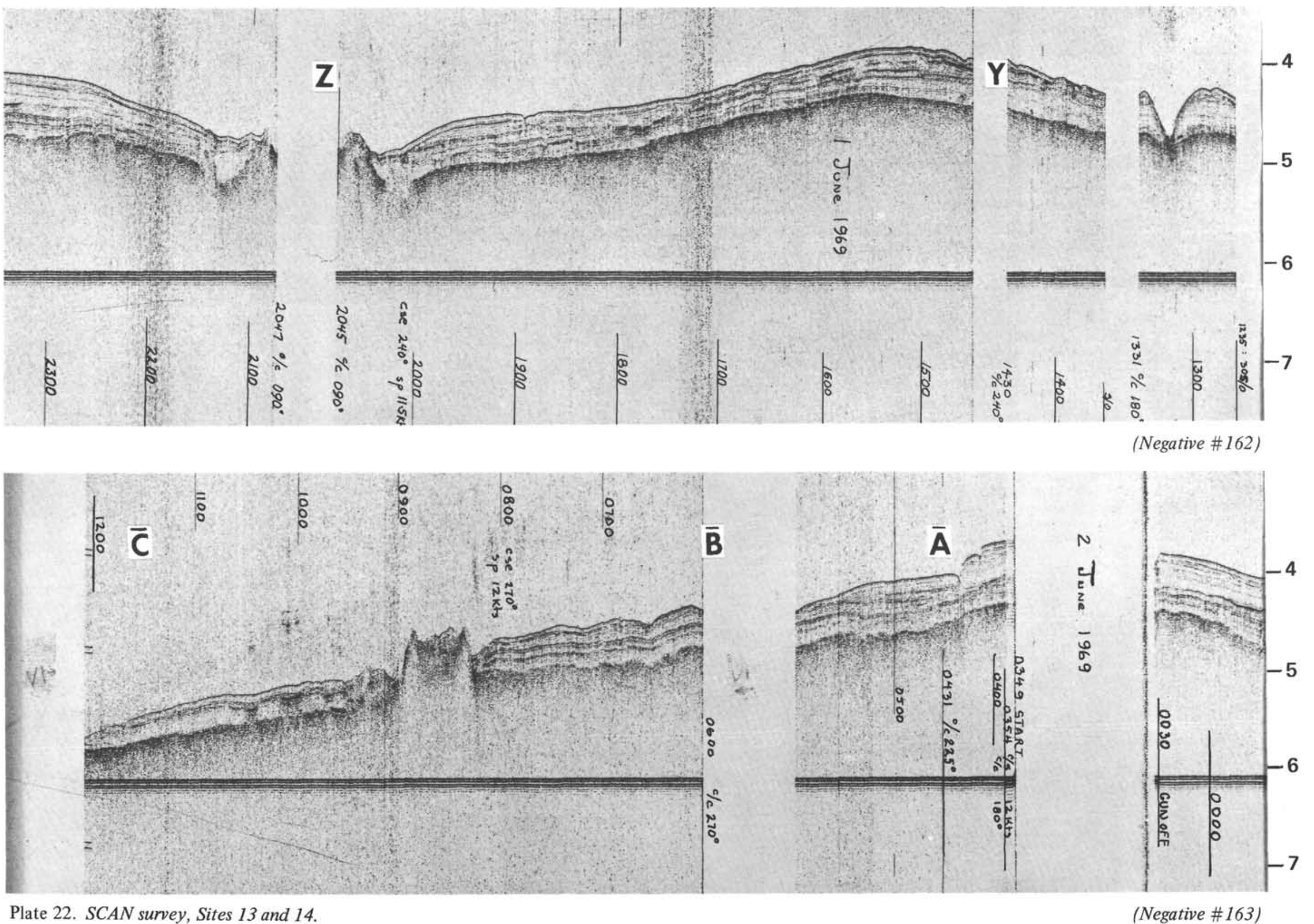

Plate 22. SCAN survey, Sites 13 and 14 . 


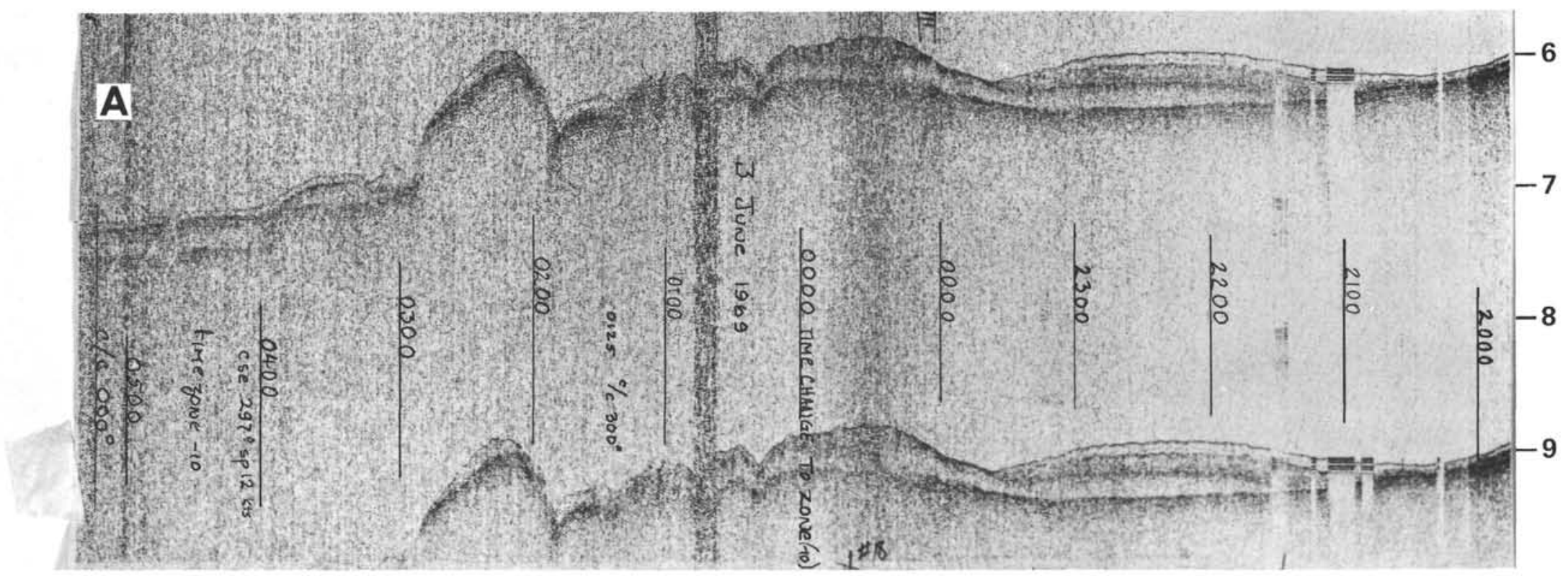

(Negative \# 164A)
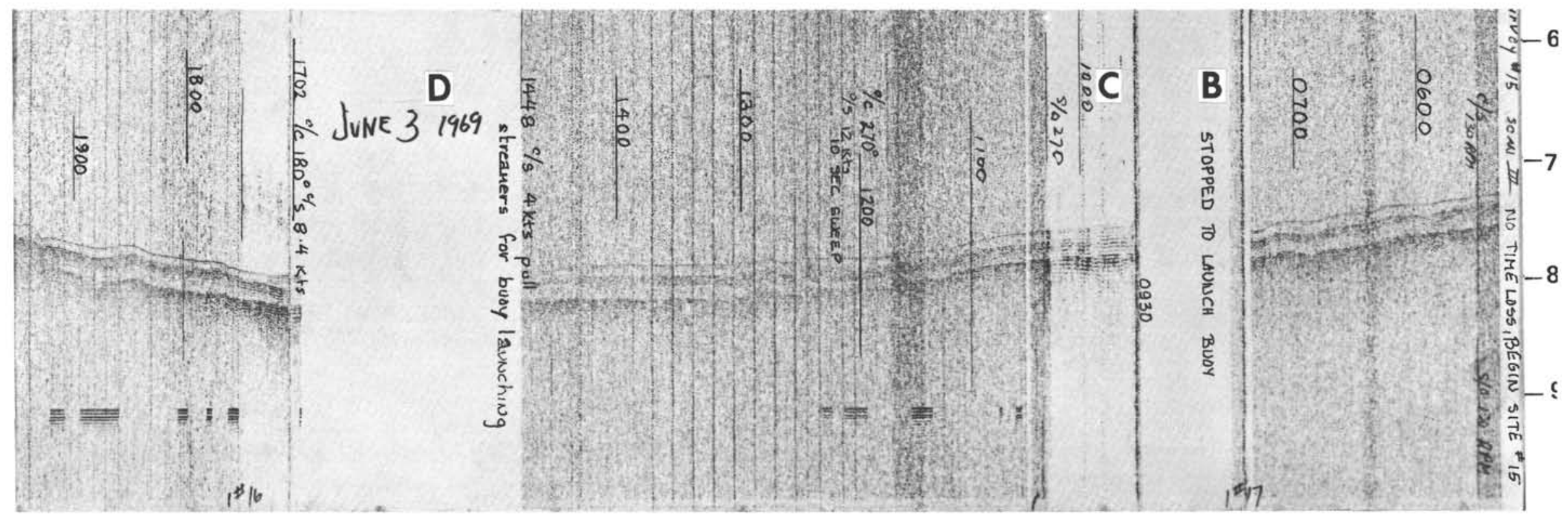

Plate 23. SCAN survey, Site 15. 

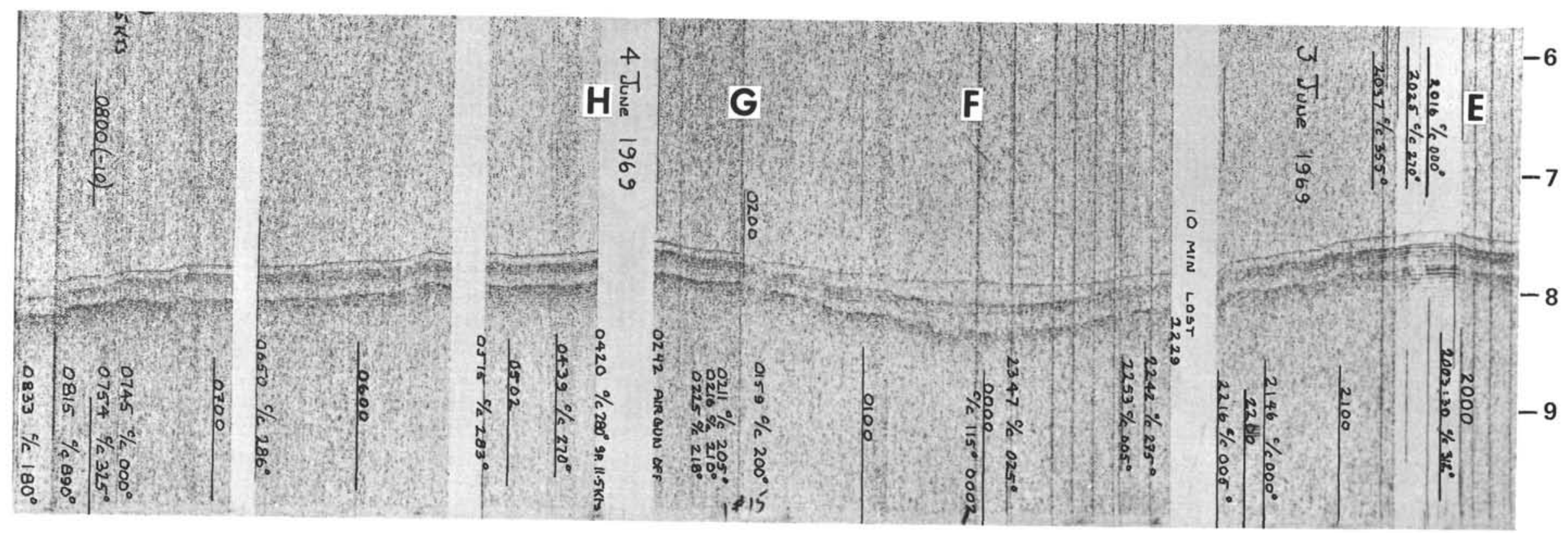

(Negative \#165)
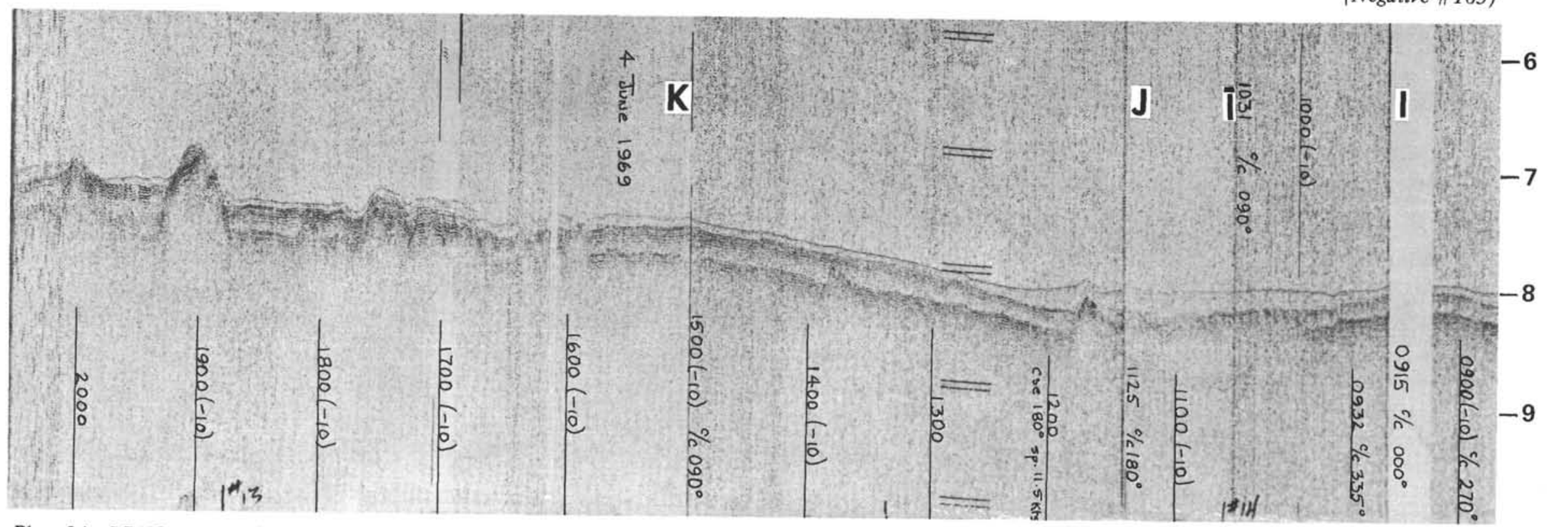

Plate 24. SCAN survey, Site 15. 


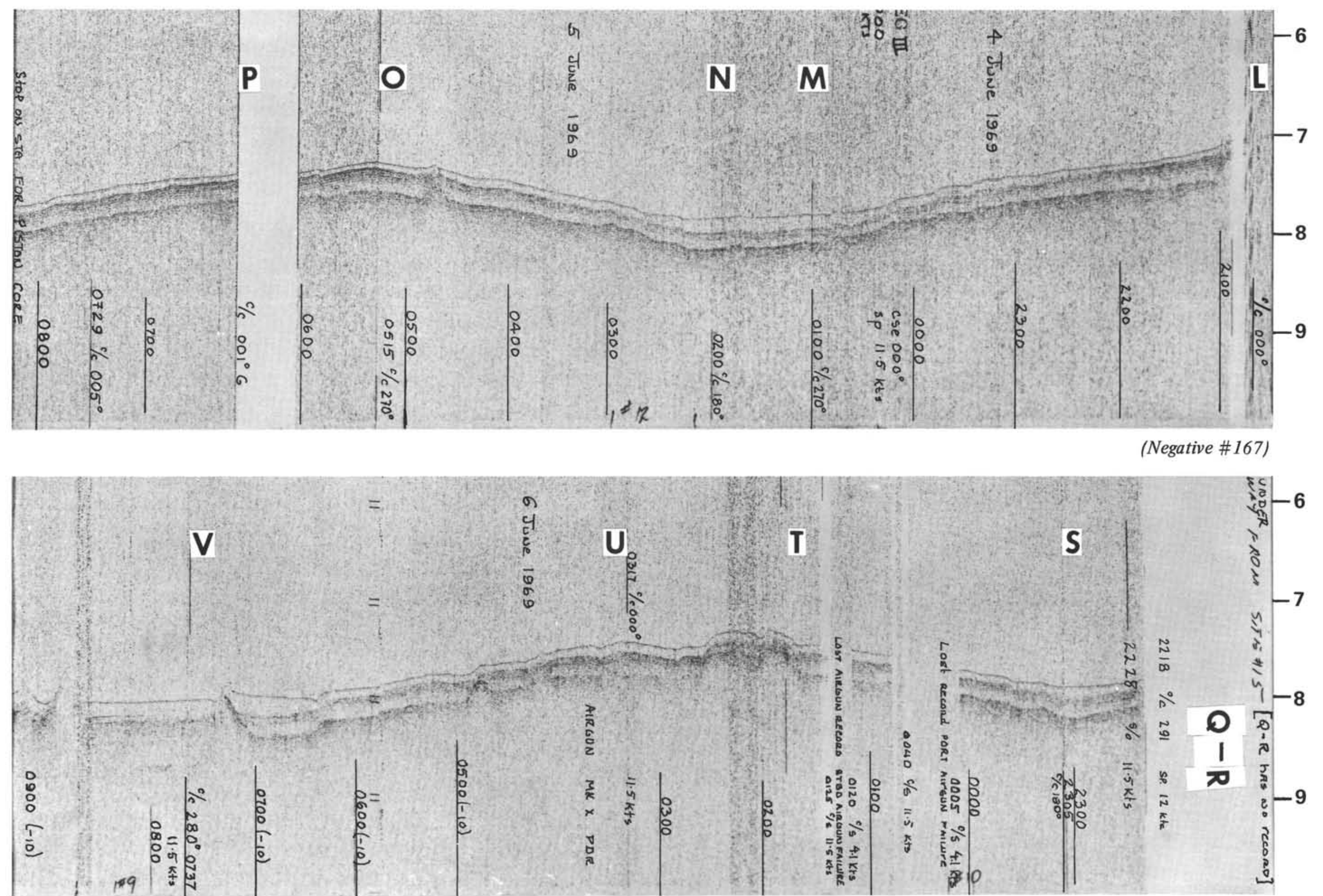




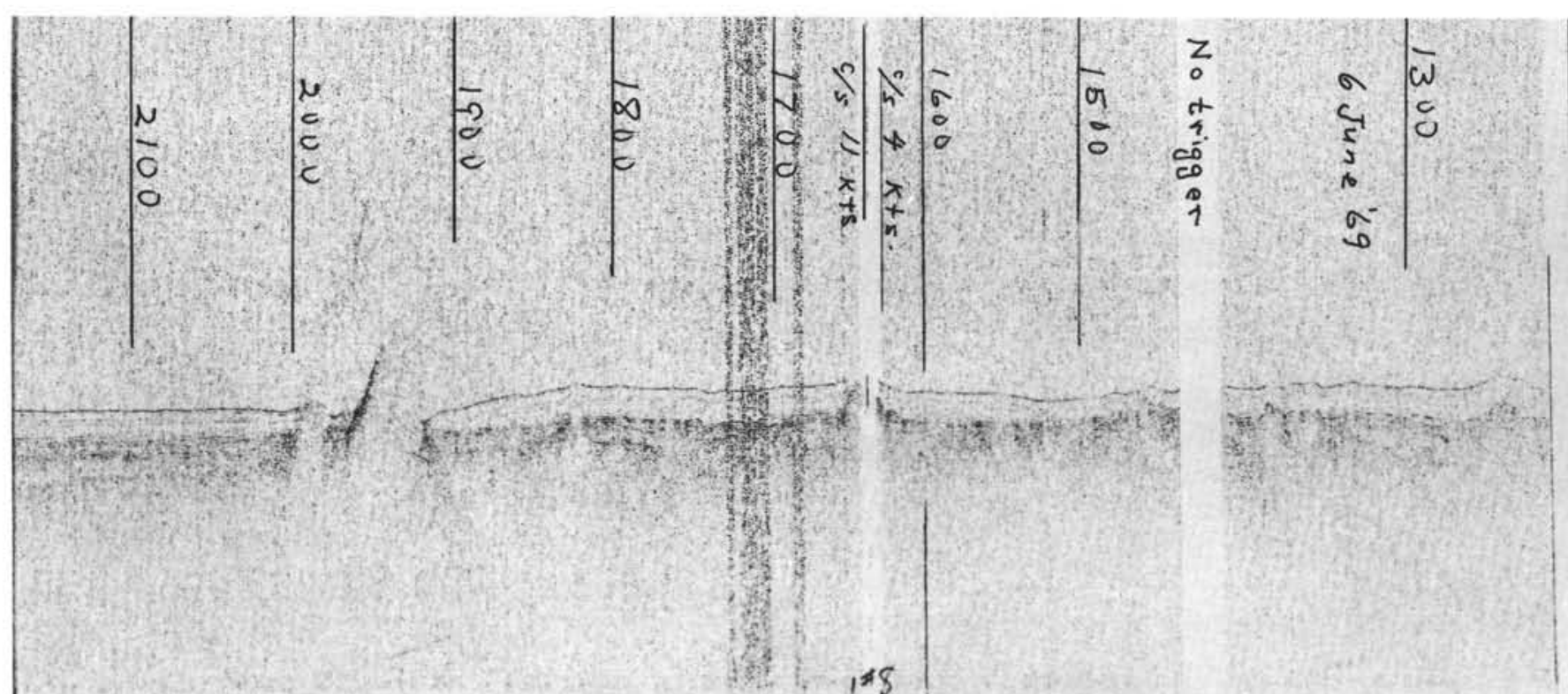

Plate 26. SCAN between sites.

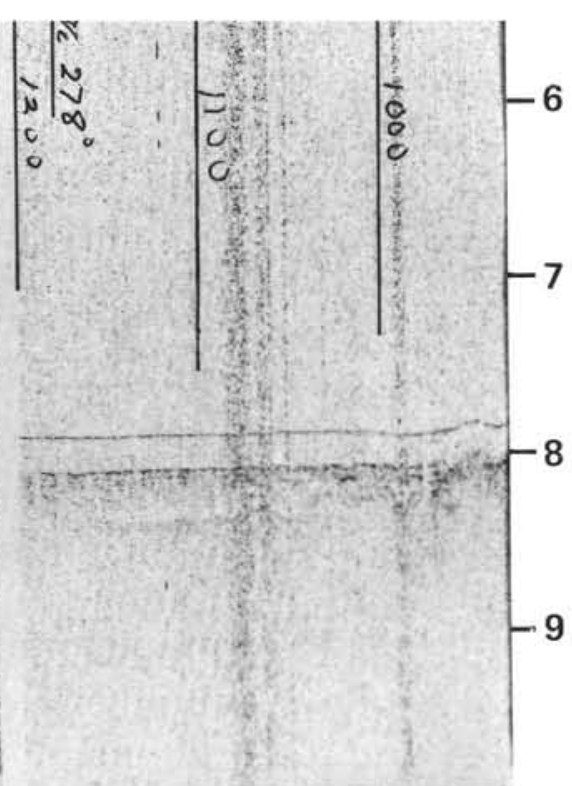

(Negative \# 170) 


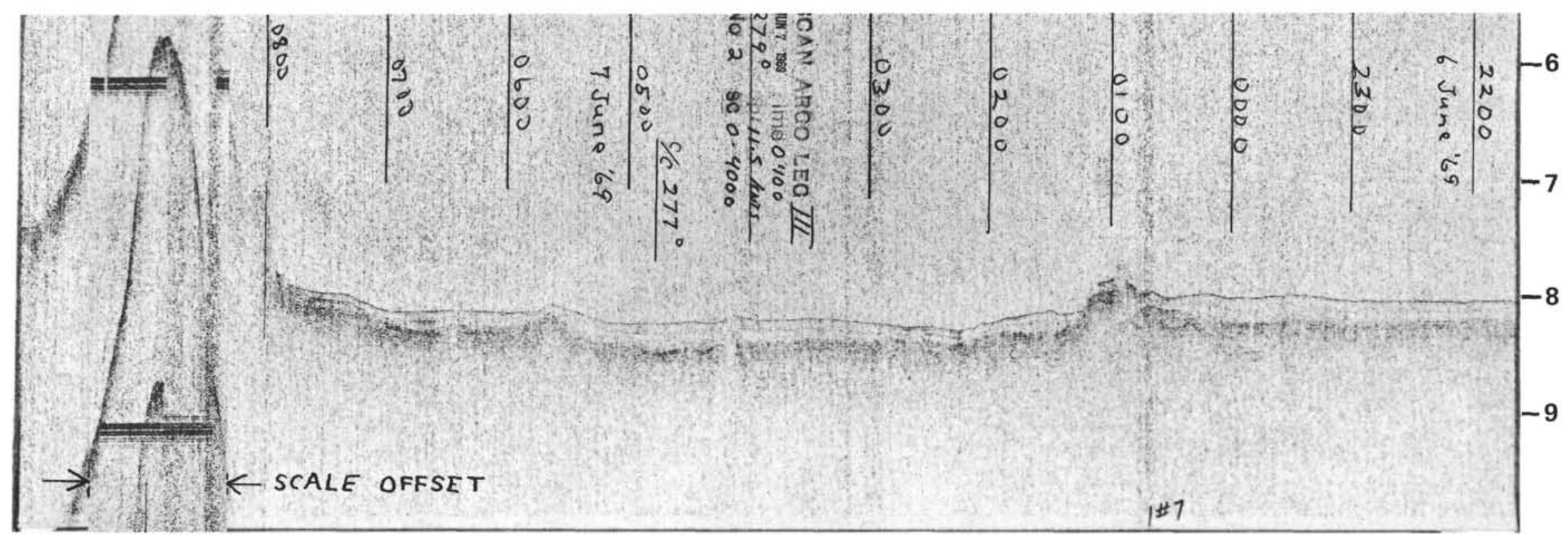

(Negative \#171)

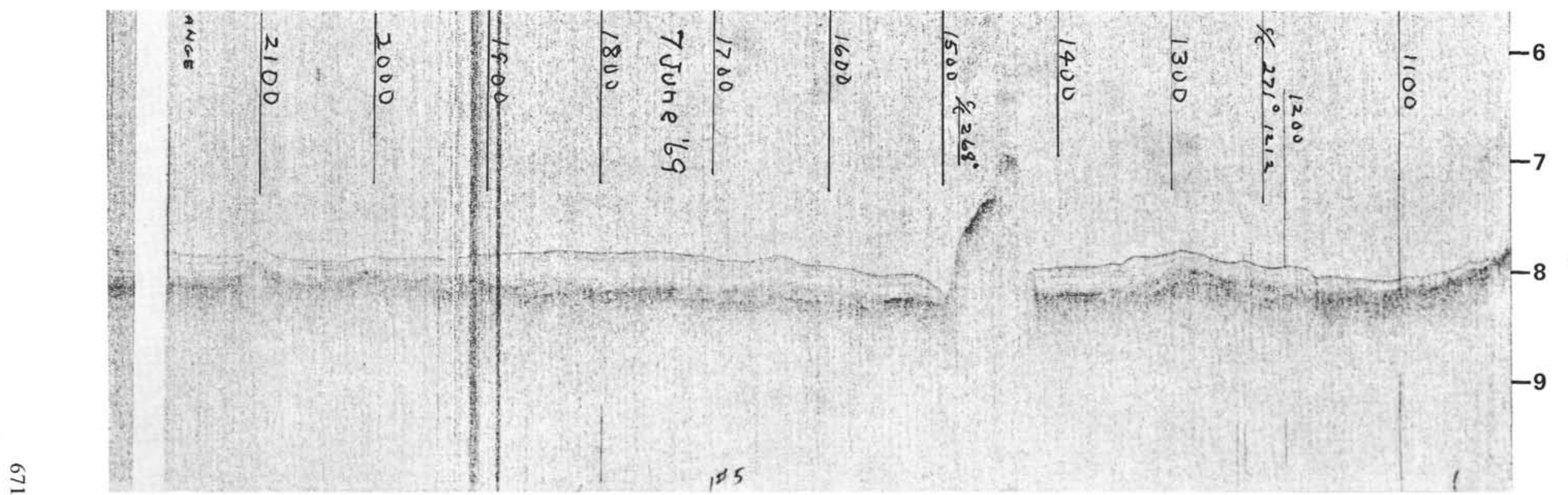



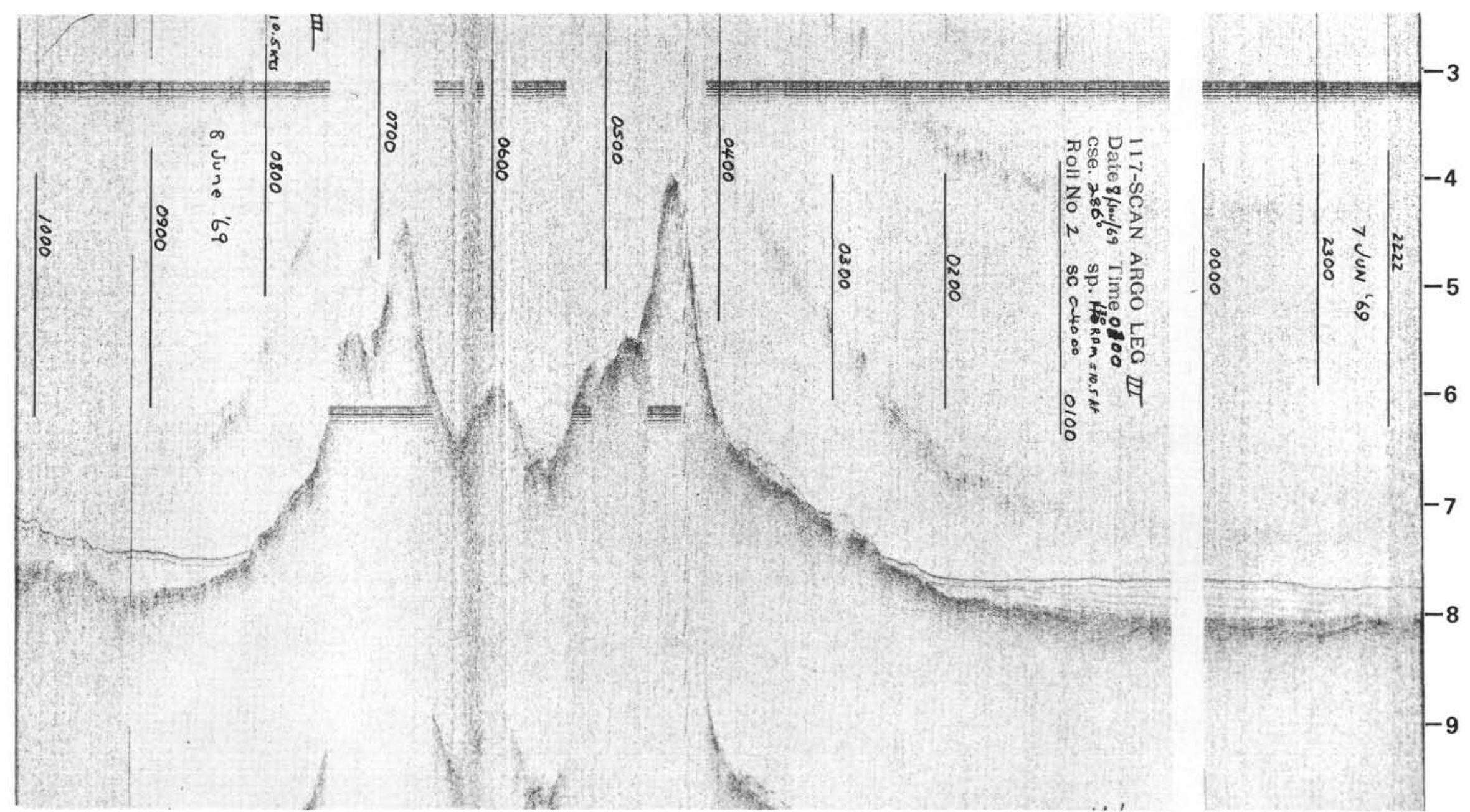

Plate 28. SCAN between sites. 


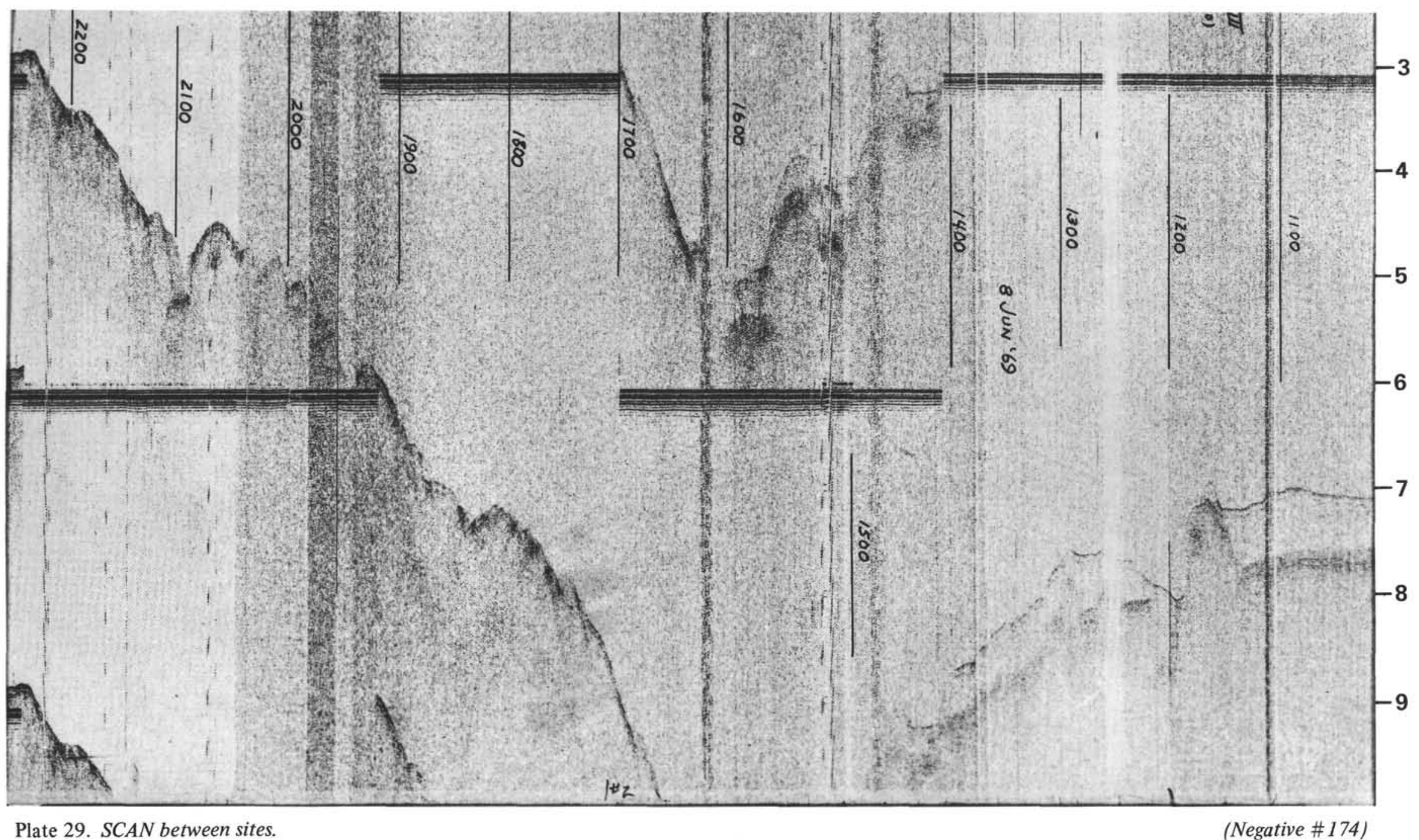




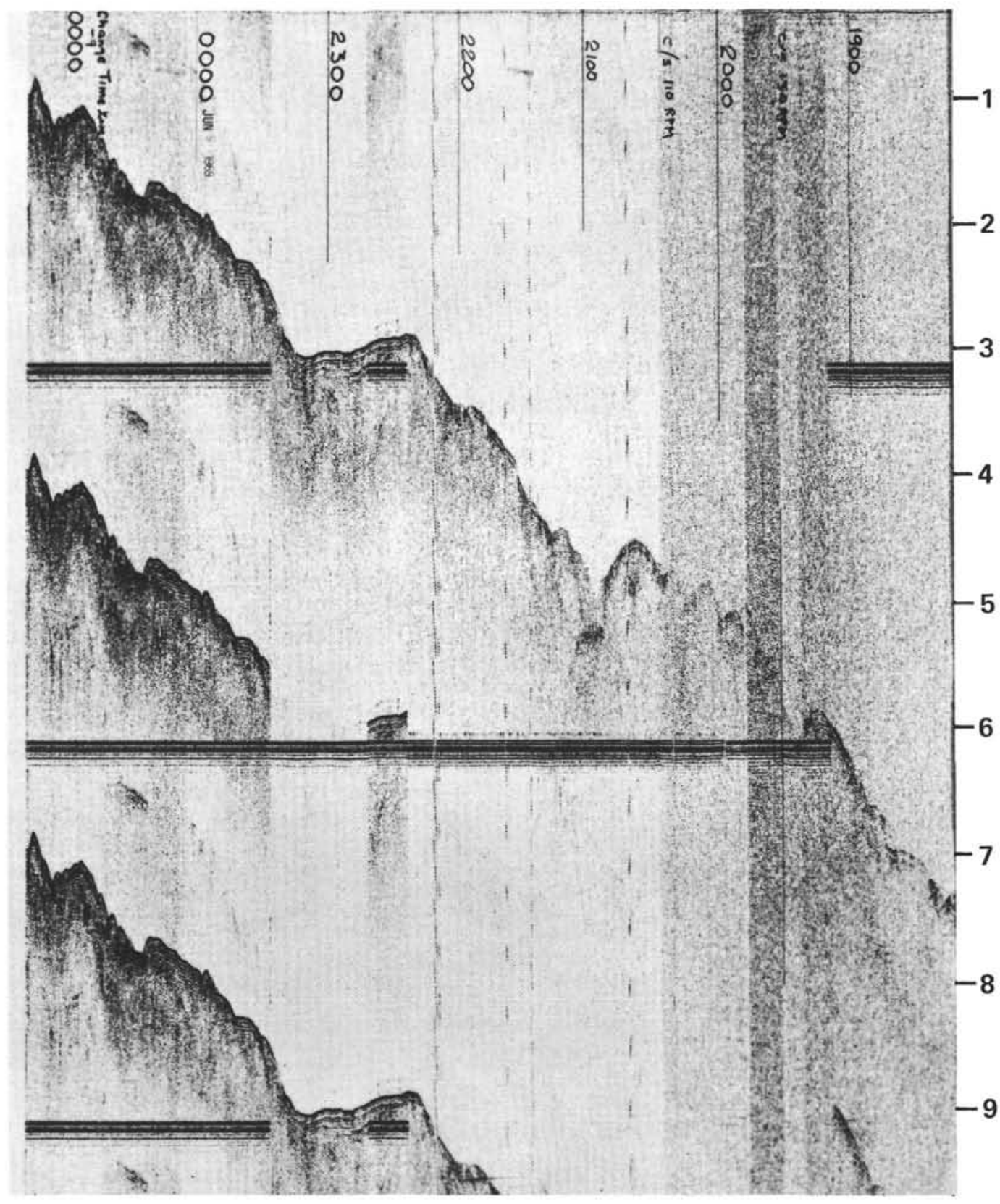

Plate 30. SCAN between sites.

(Negative \#175) 

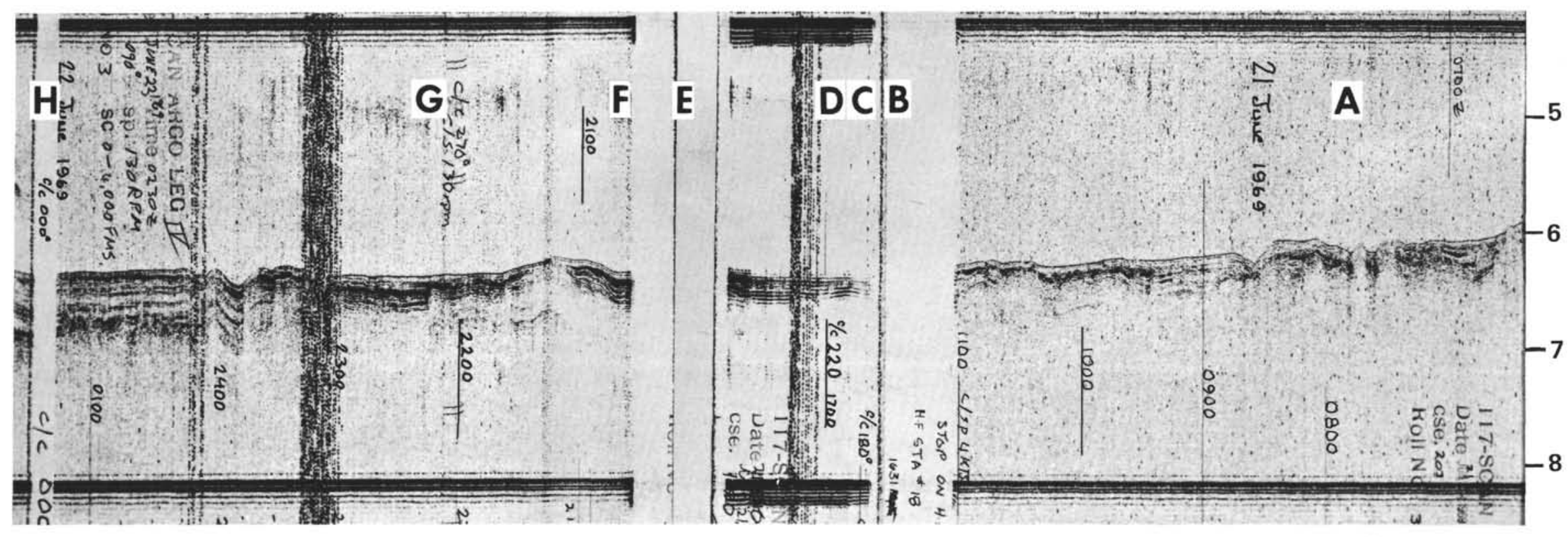

(Negative \#186)
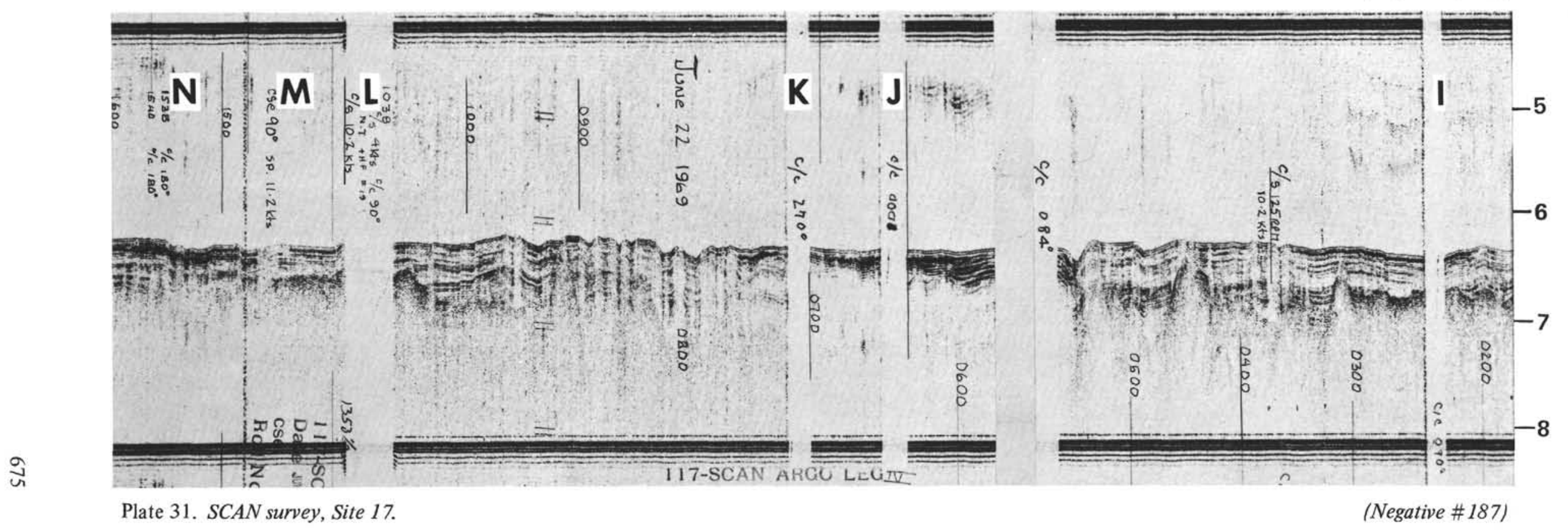

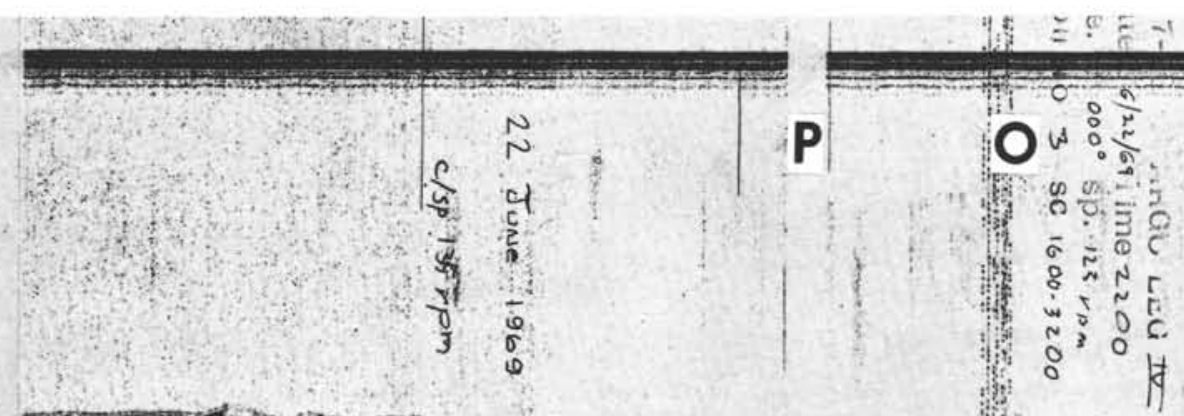

\section{Ow: 0 : $: \frac{\pi}{2}$}

$\bar{a}=\frac{1}{2}$

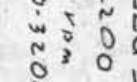

4.

17. MY

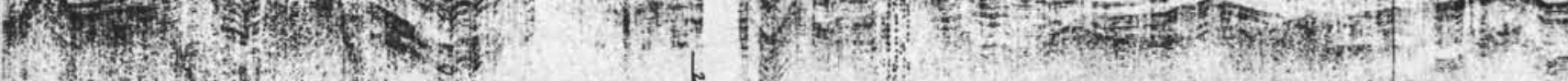
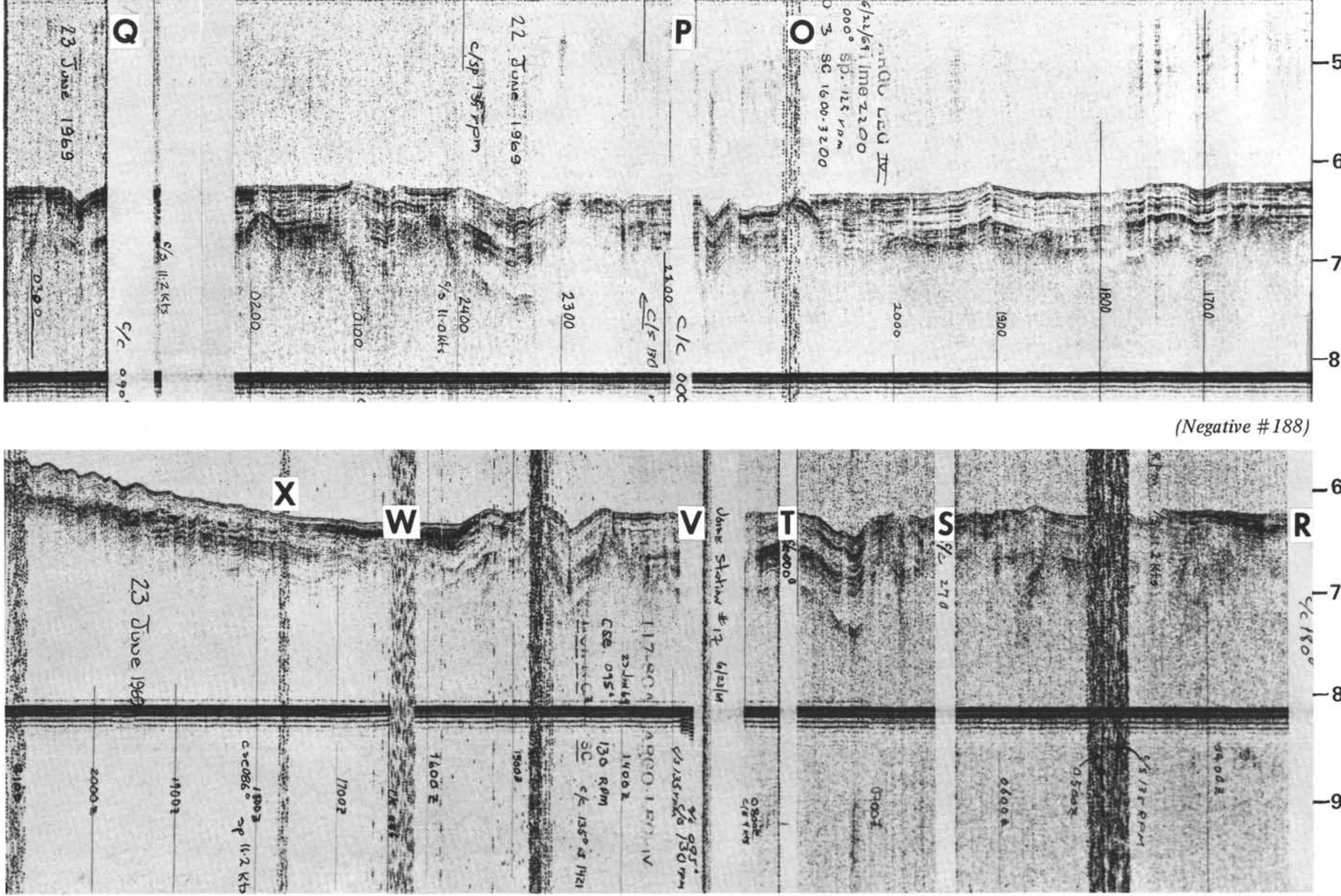

Negative \# 188) 


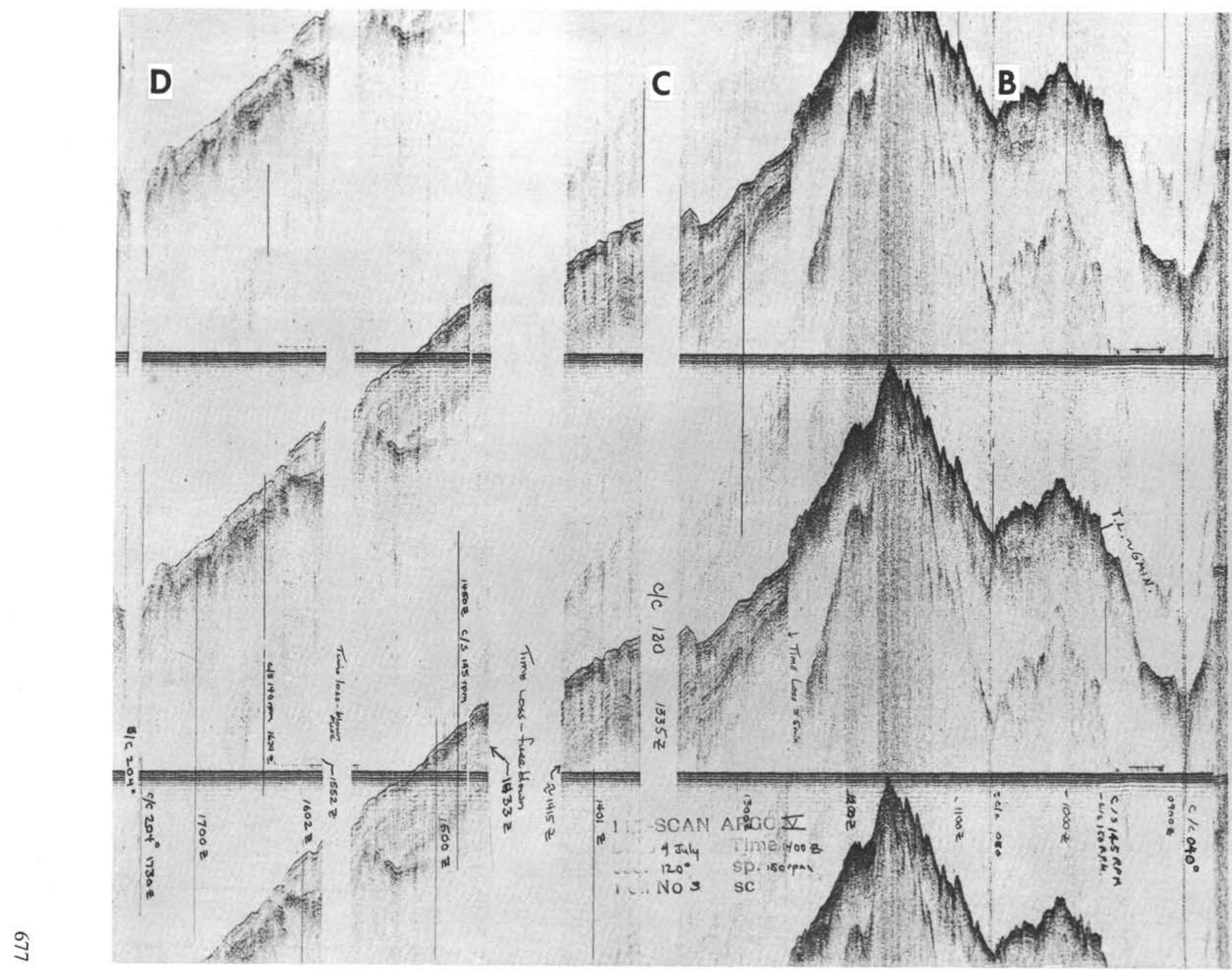

Plate 33. SCAN survey, Site $18 A$.

A

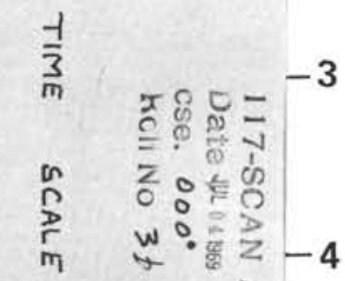

$x$
$\rightarrow 7$

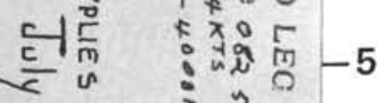

бod "

$\sigma$

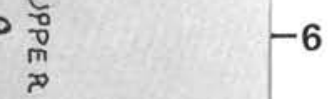

3

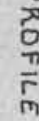

紊 

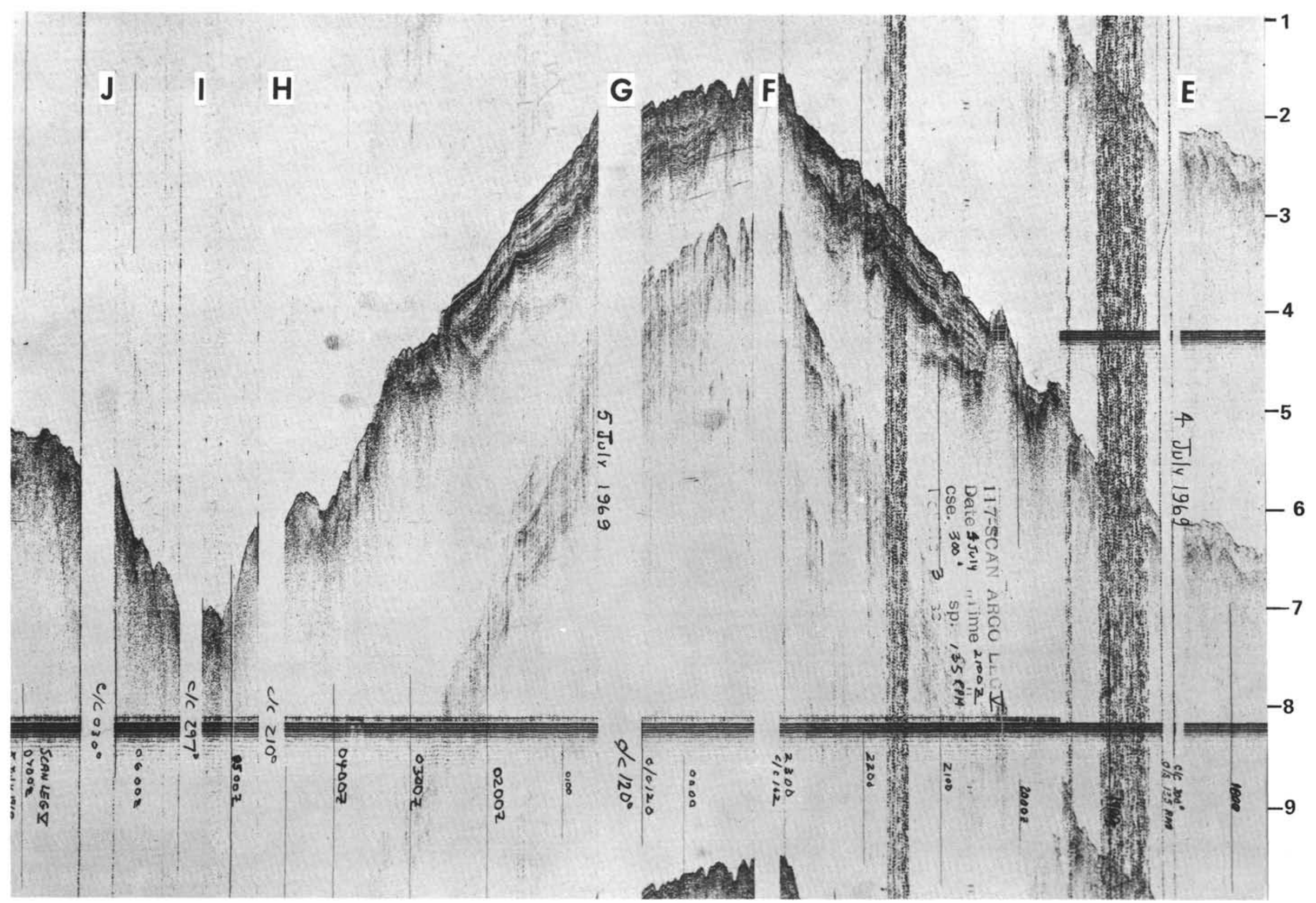

Plate 34. SCAN survey, Site $18 A$. 


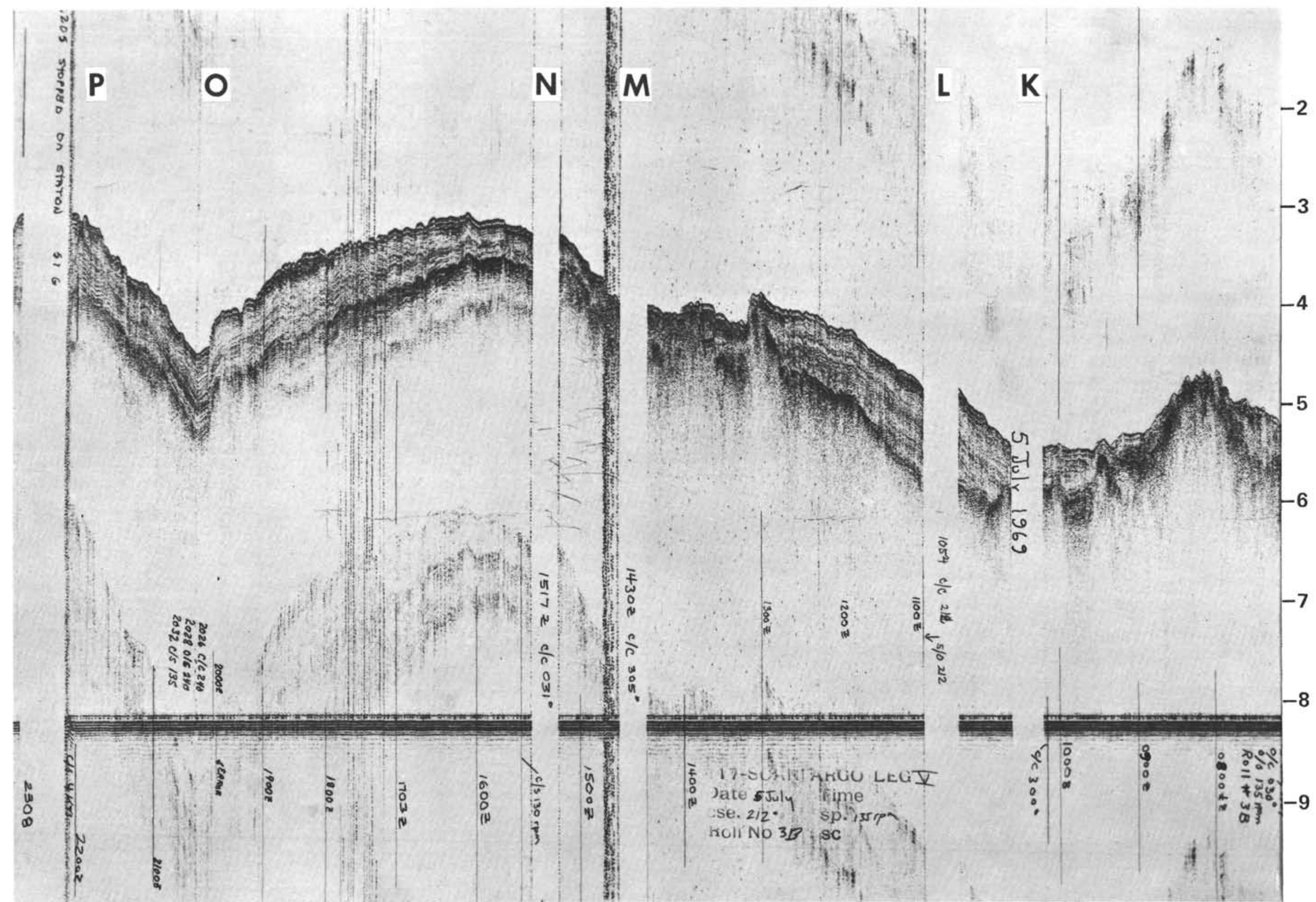

Plate 35. SCAN survey, Site 18A. 

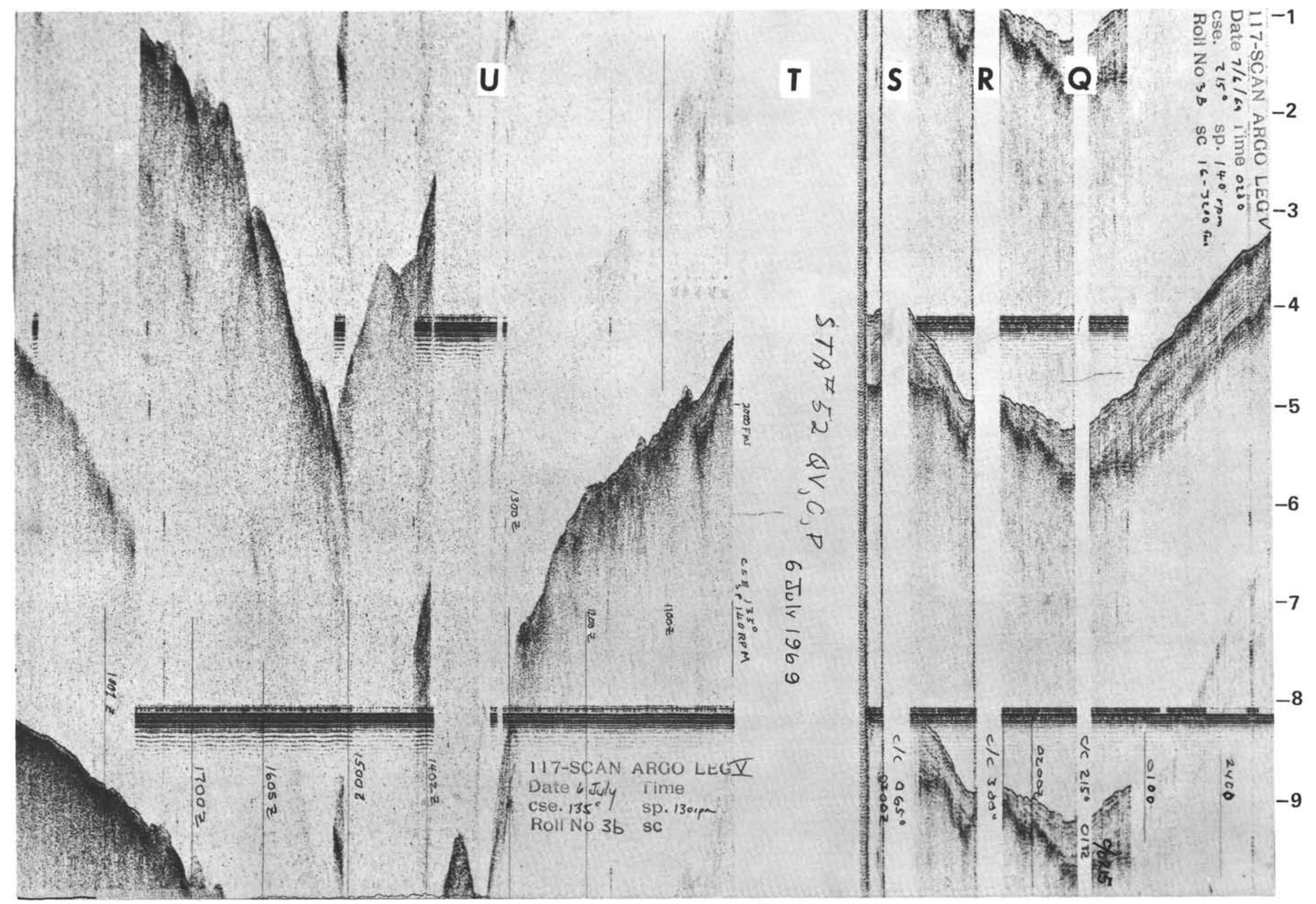

Plate 36. SCAN survey, Site $18 A$. 